\title{
Ceramic Provenance and the Regional Organization of Pottery Production during the Later Formative Periods in the Valley of Oaxaca, Mexico: \\ Results of Trace-element and Mineralogical Analyses
}

Leah D. Minc

100 Radiation Center

Oregon State University

Corvallis, OR 97331

Leah.Minc@oregonstate.edu

R. Jason Sherman

Department of Anthropology

University of Wisconsin-Milwaukee

Milwaukee, WI 53201

shermanr@uwm.edu

Christina Elson

Robert H. Smith School of Business

University of Maryland

College Park, MD 20742

Christina.elson@rhsmith.umd.edu

Marcus Winter

Archaeology Section

Centro INAH Oaxaca

Oaxaca de Juárez, Mexico

winteroax@prodigy.net.mx

Elsa M. Redmond

Division of Anthropology

American Museum of Natural History

New York, NY 10024-5192

eredmond@amnh.org

Charles S. Spencer

Division of Anthropology

American Museum of Natural History

New York, NY 10024-5192

cspencer@amnh.org

\section{Corresponding author: Leah Minc}




\section{INTRODUCTION}

In this study we address the challenge of establishing ceramic provenance at a spatial scale useful for shedding light on intra-regional networks of production and exchange within the Valley of Oaxaca during the later Middle through Terminal Formative. Situated in the highlands of southern Mexico, the Oaxaca Valley represents one of our best documented cases of primary state formation, consolidation, and decline in the New World (e.g., Blanton et al., 1999; Joyce, 2010; Marcus, 1998, 2008; Marcus and Flannery, 1996; Spencer, 2010; Spencer and Redmond, 2004). Current models of political and economic processes in the ancient Zapotec state continue to stress intravalley interactions, placing a high premium on being able to monitor production and exchange at the local level. Such a focus requires that we distinguish source areas and track the movement of ceramic vessels over shorter distances, which in turn requires finer-grained spatial data and a more detailed understanding of raw material resource distributions.

Our goal here is to define and describe the "ceramic geography" for the central Oaxaca Valley, i.e., where ceramics were produced and the spatial resolution obtained in mapping those sources. Prior trace-element analyses of Formative ceramics have largely focused on the role of inter-regional trade in pottery vessels. These studies have illustrated that ceramics from important early centers in the valley can be distinguished from those of neighboring highland areas, as well as from both the Pacific and Gulf coasts, and have indicated that ceramic vessels moved over long distances, although the specific mechanisms varied by time period and region (Blomster et al., 2005; Herrera et al., 1999; Joyce et al., 2006; Redmond and Harbottle, 1983; cf. Stoltman et al., 2005). However, these studies have not explored chemical and mineralogical variation within the Valley of Oaxaca to any great extent, and are not sufficiently detailed to address issues of exchange at the intra-regional level. Yet such a scale is necessary to examine long-standing questions - such as the organization of craft production and the rise of early market systems - in the Valley of Oaxaca.

In order to provide a more comprehensive view within the Valley of Oaxaca, we initiated a program of extensive raw material sampling, trace-element characterization, and petrographic analyses of field clays to establish a robust, regional framework for monitoring ceramic exchange within region (Minc and Sherman 2011). Here we apply this regional perspective to the task of identifying the probable sources of ceramic production within the heartland of the early Zapotec state during the later Middle through Terminal Formative periods (700 BCE - 200 CE), a time span marked by centralization of political control under the new regional capital at Monte Albán (Balkansky, 1998; Elson, 2007; Marcus and Flannery, 1996; Spencer and Redmond, 2001, 2004; Sherman et al., 2010). The result is a relatively fine-grained assessment of ceramic provenance that will support detailed reanalyses of long-standing models for the emergence of specialized production and intra-regional exchange during the early stages of Zapotec state formation.

\subsection{Background: Regional Clay Characterization}

The Valley of Oaxaca is a high intermontane valley situated at ca. $1500 \mathrm{~m}$ and sharply bounded by the steep topography of the Sierra Madre del Sur. Bedrock is at or near the surface through much of the surrounding uplands, and differences in bedrock composition strongly affect the mineral content and chemistry of valley clays (Fig. 1). As mapped by the Mexican geological survey (INEGI, 1994, 1:250000 and 1:50000), the major geological units within the valley include (1) the Oaxacan Metamorphic Complex (consisting of PreCambrian orthogneisses, basal meta-anorthosite and meta-granite, and related metamorphic rocks) that forms much of the western piedmont (Keppie et al. 2001; Keppie et al. 2003; Loaeza García and Mendoza Torres, 2007; Mora et al., 1986:224; Ortega-Gutiérrez, 1981; Ortega-Obregón et al., 2003); (2) Cretaceous and Tertiary sedimentary rock associations (ranging from fine-grained mudstone and siltstone, to coarser-grained sandstones and conglomerates) that outcrop along a discontinuous arc running from NW to SE (Ferrusquía-Villafranca and Ruiz-González, 2007; UrrutiaFucugauchi and Ferrusquía-Villafranca, 2001); (3) large expanses of volcanic rocks - primarily andesite - of Tertiary (Oligocene or Miocene) age that bound the eastern arm of the valley and extend south along the eastern side of the southern arm (Martínez-Serrano et al., 2008; and (4) more recent volcanic materials including ash-fall deposits, 
indurated tuff, and ignimbrites of rhyolitic to rhyodacitic composition, largely limited to the eastern and central portions of the valley (Martínez-Serrano et al., 2008; Urrutia-Fucugauchi and Ferrusquía-Villafranca, 2001) (for details see Minc and Sherman, 2011).

While each of these geological units contributes a distinctive suite of minerals and a unique geochemistry which facilitates the determination of ceramic provenance, the lack of homogeneity within some bedrock units (notably the Oaxaca Metamorphic Complex), the extensive weathering, erosion, and redeposition of sediments on the valley floor, and the wide-spread, air-borne distribution of some volcanics (primarily the tuff and ignimbrites) have created complex patterns of mineral and chemical variation in valley soils. Further complicating the picture is the spatial discontinuity of some geological units (such as the various calcareous sedimentary sequences and the Tertiary andesites), potentially leading to the formation of highly similar clays in widely separated parts of the valley.

In order to develop a regional trace-element and mineralogical database for the determination of ceramic provenance within this complex landscape, we conducted extensive raw material sampling as part of the Oaxaca Clay Survey (OCS). Clays were initially sampled at 135 locations throughout the valley (Minc and Sherman, 2011); a second survey addressed gaps in our coverage and brought our total of clay sampling locations to 320 . All clays were formed into ceramic tiles and fired under conditions approximating traditional pottery production $\left(800^{\circ} \mathrm{C}\right.$ for 1 hour in an oxidizing environment) and their elemental concentrations characterized via instrumental neutron activation analysis (INAA); a $12.5 \%$ sample was also analyzed for mineral composition using optical petrography of ceramic thin-sections. The chemical composition of valley clays was then modeled using spatial interpolation to create a series of contour map revealing how element concentrations vary over space. Regional trends were explored for a suite of 29 elements (Al, As, Ba, Ca, Ce, Co, Cr, Cs, Dy, Eu, Fe, Hf, K, La, Lu, Mn, Na, Nd, Rb, Sc, Sm, $\mathrm{Ta}, \mathrm{Tb}, \mathrm{Th}, \mathrm{Ti}, \mathrm{U}, \mathrm{V}, \mathrm{Yb}$, and $\mathrm{Zn}$ ) and mapped using the Minimum Curvature spline method for contouring irregularly spaced geophysical data (Briggs, 1974; Smith and Wessel, 1990). Following interpolation, a 1-km reference grid of smoothed concentration values was generated for each element, cropped to correspond to the Valley of Oaxaca drainage basin, against which ceramic composition data can be compared. (For details on methodology, see Minc and Sherman, 2011; note that all element distribution maps have been updated based on the expanded sample of clays).

The resulting regional model of clay composition offers clear advantages for ceramic provenance determination by indicating the scale and spatial patterning of chemical variability across the landscape, and by identifying areas with a unique clay composition as well as areas with broadly similar composition. Further, the even and relatively comprehensive coverage provided by the model potentially allows for finer resolution in provenance determination as well as the ability to match ceramics to locations on the landscape not represented directly by clay samples. Finally, the in-depth understanding of the relationship between geology and clay composition serves to highlight key elemental ratios for distinguishing between possible provenance assignments, and enables us to assign a general source area even in the absence of a strong match between pottery and clays.

Utilization of this regional clay model to establish provenance involves a four-step process. Beginning with the pottery, we first evaluate the chemical data to define reference groups of ceramics having similar compositions. Second, we compare these reference groups to our clay database and to our regional model of clay composition, in order to identify the locations(s) of best fit. We then utilize the ceramic petrography data as an independent measure to assess the validity of those matches, based on mineral composition. As a final step, we consult regional site surveys to assign production to the most likely contemporary site(s).

\subsection{Ceramic Sample: Sites and Wares}

Our spatial focus is on the northern Valle Grande and the Ocotlán subregions of the valley. Extending roughly 30 $\mathrm{km}$ south of the new regional capital at Monte Albán, this area includes all the major bedrock types found within the valley (Fig. 1) and contains key settlements involved in state formation. Our sample includes domestic debris from five of these communities: (1) Monte Albán ( $N=91)$, destined to become the dominant polity in the valley; (2) 
Yaasuchi ( $\mathrm{N}=56)$, a mid-level center and possible dependent of Monte Albán located ca. $15 \mathrm{~km}$ south of the capital in the northern Valle Grande (Sherman, 2005); and (3) three sites at Tilcajete, all located more than $20 \mathrm{~km}$ from Monte Albán in the Ocotlán subregion, that were occupied sequentially. The earlier Tilcajete settlements (EI Mogote [ $\mathrm{N}=51]$ and El Palenque [ $\mathrm{N}=72]$ served as the capitals of an independent polity that resisted incorporation by the expanding Monte Albán state (Spencer and Redmond, 2001, 2006), while the third (Cerro Tilcajete [N=168]) was established in the Terminal Formative period after Monte Albán subjugated and incorporated the Ocotlán subregion (Elson, 2007; Spencer and Redmond, 2001).

This sample is supplemented by ceramic material from two apparent Formative ceramic production sites in the northern Valle Grande. Salvage excavations at Cuilapan, located just $6 \mathrm{~km}$ southwest of Monte Albán, uncovered the remains of three cylindrical kilns, two of which are attributed to the Formative period (Blanton et al. 1982:254; Markens et al., n.d). No obvious kiln wasters were encountered in these collections; however, in an attempt to establish a chemical signature for this important site, a sample of 22 Formative sherds recovered from the kilns was selected for INAA.

San Agustín de las Juntas, located $7 \mathrm{~km}$ southeast of Monte Albán, was first identified during regional site survey as a potential ceramic producer based on the very high densities of sherds that covered the surface: survey teams complained that "casi no se puede ver la tierra por los tepalcates" (Blanton et al., 1982:254; Feinman, 1986:356357). Salvage operations in 1979 by Hébert Montaño N. confirmed its status as a major Late Formative ceramic producer, with the excavation of kilns and thick middens of production debris (Winter, 1984:195). Vessels apparently produced at this site include gris conical bowls with comb-incision of the interior of the base (a type known as G.12) and vertical-necked jars with bridge-spout handles, some with applique masks (Winter 1984:195) Our sample comprises 39 Formative sherds from production contexts, including 12 wasters displaying vitrified pastes, blistered surfaces, and warped or twisted forms.

In all, a total of 500 Formative vessels and four pieces of daub were analyzed for trace-element composition as part of this study. Well-established ceramic chronologies (Caso et al., 1967; Drennan, 1976; Winter, 1976) assign these samples to the periods preceding and surrounding state formation, including the Rosario phase (700-500 BCE), Early Monte Albán I (Early MA I; 500-300 BCE), Late Monte Albán I (Late MA I; 300-100 BCE), and Monte Albán II (MA II; 100 BCE - $200 \mathrm{CE}$ ), although some ceramic types may span more than one of these periods.

Four dominant wares are represented in our sample: crema, gris, amarillo-anaranjado, and café - defined in terms of paste color, texture, and type of inclusions (Caso et al., 1967:18). Both the buff-colored crema and the brown café pastes contain a high percentage of large, somewhat angular inclusions, and have been attributed to coarser upland or residual clay sources originating in the valley piedmont (Shepard, 1967). In contrast, the gris and amarillo wares are generally finer-textured and have been interpreted as alluvial or transported clays found on the valley floor (Payne 1994:8). These latter two wares are distinguished based on color and firing conditions: the dark gray gris ware represents smudging in a reduced-oxygen environment, while the bright yellow-orange amarillo ware results from an open-air or well oxygenated environment (Caso et al., 1967:18).

\section{METHODS}

\subsection{Chemical Characterization}

Activation analyses were initiated at the University of Michigan's former Ford Nuclear Reactor (Minc et al., 2007), and completed at the Oregon State University Radiation Center following irradiation and gamma spectroscopy protocols summarized in Minc and Sherman (2011). At both labs, element concentration values were determined on a weight-ratio basis through direct comparison with certified reference standards NIST1633A (coal fly ash) and NIST688 (basalt rock; calcium only), using published consensus values (Glascock, 2006). Check-standards (New Ohio Red Clay and NIST1633b) were included in each batch to verify accuracy and precision of results across batches and to facilitate the exchange of data; inter-lab calibrations were based on average values for these checkstandards as determined at each reactor facility. The analyses resulted in a shared suite of 33 elements: Al, Sb, As, 
$\mathrm{Ba}, \mathrm{Ca}, \mathrm{Ce}, \mathrm{Cs}, \mathrm{Co}, \mathrm{Cr}$, Dy, Eu, Fe, Hf, K, La, Lu, Mn, Nd, Na, Ni, Rb, Sc, Sm, Sr, Ta, Tb, Th, Ti, U, V, Yb, Zn, and Zr. A substantial number of cases had values below detection limits for $\mathrm{Ni}, \mathrm{Sr}, \mathrm{U}$, or $\mathrm{Zr}$, and these elements were excluded from consideration. Element concentrations were transformed to $\log (10)$ values for statistical analyses.

\subsection{Ceramic Petrography}

Petrographic analysis was conducted on a sub-set of 40 pottery thin sections representing the main ceramic composition groups and the full range of ceramic wares included in the study. Both qualitative and quantitative data were collected for each thin section using a standard petrographic microscope, following methods detailed in Minc and Sherman (2011). Qualitative analysis began with the identification of the overall suite of minerals evident in the thin section based on their optical properties under both plane-polarized and cross-polarized light. Quantitative data were collected using a point-counting technique similar to that described by Stoltman (1989, 1991). Using a movable stage, between 150 and 300 points were assessed within a grid of 1-mm intervals, and the point under the crosshairs recorded as matrix, void, or inclusion. If the crosshairs landed on an inclusion, the mineral was identified and the grain size recorded as silt $(<.0624 \mathrm{~mm})$, fine sand $(.0625-.249 \mathrm{~mm})$, medium sand $(.25-.49 \mathrm{~mm})$, coarse sand $(.50-.99 \mathrm{~mm})$, very coarse sand $(1.00-1.99 \mathrm{~mm})$, or gravel $(>2.00 \mathrm{~mm})$ (following Stoltman, 1989:149, 1991:108). A grain size index based on an ordinal scale of 1 to 5 (fine $=1$, medium $=2$, coarse $=3$, very coarse $=4$, gravel $=5$ ) was also calculated to represent the mean of the sand- and gravel-sized grains in each sample (Stoltman, 1991:108-109).

\subsection{Assessing Temper vs. Natural Inclusions}

Determining whether mineral inclusions are naturally occurring or cultural additions has important implications for establishing provenance, since the addition of temper significantly modifies the trace-element and mineralogical signature of natural clays (Neff et al. 1988, 1989; Sterba et al. 2009). While it can be notoriously difficult to distinguish temper from natural inclusions, several lines of evidence have been proposed to identify cultural additions or mixing of clays. These include (1) the co-existence of minerals from distinct geological contexts; (2) a distinctive suite of minerals in the coarser sand-sized fraction as compared to the silt- and fine sand-sized fractions; and (3) the predominance of one size-class of inclusions, visible as a narrow unimodal or strongly bimodal size distribution within the sand-sized particles (Quinn 2013:156-168; Rice 1987:411; cf. Shepard 1965:161-162).

The first criterion is not particularly useful in the Valley of Oaxaca given the degree to which clays may be naturally mixed there. We therefore focus on the second and third criteria: qualitative comparisons of the size-distribution of minerals that may reflect different geological parent materials, as well as quantitative measures of particle size (using the average grain-size index) and degree of sorting within the sand fractions (using Pielou's [1977] evenness index $J^{\prime}$, with a higher value of $J^{\prime}$ indicating a more even distribution of inclusions across a range of size classes and hence poorer grain-size sorting). Natural clays typically display a weathering gradient, from coarse, relatively poorly sorted (high size index, high J') primary or residual clays, to increasingly fine and well-sorted (low size index, low J') redeposited clays, although parent material and depositional context strongly affect the weathering characteristics of resultant mineral grains. We suggest that obvious departures from that gradient may represent modifications of ceramic pastes. In particular, since potters typically add temper with a larger grain-size than naturally occurring inclusions (Quinn 2013:161), we anticipate that the addition of temper would result in a higher grain-size index and a lower value of J' (reflecting the predominance of a single grain-size class), relative to clays naturally occurring within the region.

\subsection{Identifying Ceramic Composition Groups}

Statistical analysis of trace-element data followed now standard procedures for the definition and verification of compositional reference groups, as applied in those situations where clear evidence of production loci-such as kilns, firing features, or wasters - are lacking (Neff, 2002). These steps include (1) the use of exploratory data analysis techniques such as bivariate plots and cluster analysis to partition the dataset into groups of samples which apparently share a distinctive composition; (2) the testing and refinement of each of these preliminary 
groups using the jack-knifed multivariate Mahalanobis distance measure to create statistically homogeneous reference groups; and (3) classification of remaining samples into their most likely compositional group using multivariate measures of similarity, including discriminant analysis and the Mahalanobis distance statistic (Bishop and Neff, 1989; Glascock, 1992; Glascock and Neff, 2003; Neff, 2002). Owing to the small sample sizes for some reference groups, it was necessary to first reduce the dimensionality of the data set in order to employ the Mahalanobis distance statistic; thus, principal components analysis was employed to identify the major dimensions of variability within the matrix of element concentrations. A robust PCA was computed on the covariance matrix comprising both Formative ceramic and clay samples; the most extreme $5 \%$ of cases (as determined through multivariate distances) were excluded from the analysis. The first seven principal components account for $92 \%$ of covariance structure; components beyond that had little utility for discriminating among groups (see Supplemental Material). Within-group distances were then calculated based on these principal component scores rather than element concentrations.

\subsection{Establishing Ceramic Provenance}

The geographic source(s) of ceramic reference groups were determined through comparison with clays collected as part of the OCS. Using a hierarchical approach, we first assessed the general geological context of each reference group by comparing its elemental signature with those previously identified for the main geological units in the study area (Minc and Sherman, 2011). Petrographic data served as an independent measure to assess the validity of geological associations based on mineral composition, either confirming that the ceramics and clays derive from the same geological context, or alerting us to a possible spurious match or perhaps a mix of clays from disparate sources.

Based on the trace-element data, individual clays were then tested for membership in each ceramic group using the multivariate Mahalanobis $\mathrm{D}^{2}$ distance statistic as calculated on principal component scores. This metric provides a robust and fairly conservative measure of fit when reference groups are well defined, with a high probability of membership reflecting a match in composition. A similar assessment of grid points derived from the continuous spatial model allowed us to map the area(s) of the landscape with clays showing the greatest similarly to each of the ceramic composition groups, and to assess their spatial extent and location relative to prehistoric sites. As a final check on fit, each reference group was compared to potentially matching clays using a geochemical profile plot. Element values were first normalized by dividing by the grand mean for clays from the initial clay survey in order to put all elements on a common scale emphasize the range of variation within the current data set, and then plotted in geochemical order (major elements first, followed by transition metals, alkali elements, rare-earth elements, and high field strength incompatibles). Visual comparison enabled us to determine whether a clay or grid point closely approximated a specific reference group across all elements in its compositional profile, or whether there were noticeable discrepancies. This step is especially critical in making fine distinctions between alternative potential locations based on key elements or element ratios not highlighted by the generalized Mahalanobis distance measure.

\section{RESULTS}

\subsection{Tempering vs. Natural Inclusions}

The ceramicist William Payne (1994:8-9) suggested that many clays used by Formative potters in the Valley of Oaxaca contained sufficiently high levels of aplastic mineral inclusions that additional temper would have been unnecessary (cf. Shepard 1967:478-479). Further, as in our own clay survey, he found that exposed soil profiles in the Oaxaca valley often provide a range of decomposition products and that among these are well weathered clays which appear under the binocular microscope to be identical to clay bodies -- from fine to coarse -- used by Formative potters.

We concur with the assessment that Formative ceramic pastes closely approximate natural clays in the valley and are generally untempered. Our petrographic analyses of sherds indicate that the same suite of minerals generally 
occurs across all grain-size fractions, from silt to very coarse inclusions, implying that all size classes are natural weathering products from the same parent material. This pattern is similar to that noted by Fargher (2007:322323) in his analysis of gris ceramics from Monte Albán, who also suggests that all inclusions came from the same, or a similar, geological source (although he notes that sand temper derived from the same sources as clays might also be present in some sherds).

In addition, the Formative ceramics we analyzed exhibit a similar range of textures (in terms of particle size) and degree of sorting as naturally occurring clays. As an experimental approach, we created a plot of evenness ( $\left.J^{\prime}\right)$ vs. average sand grain size for field-collected clays -- the textures of which follow a curve from coarse, poorly sorted to finer, well sorted inclusions, as expected for increasing sediment maturity (Fig. 2). Note that their distribution closely approximates the maximum evenness attainable for a given grain size index, which is mathematically constrained in this analysis. That is, evenness is low $\left(\mathrm{J}^{\prime}=0\right)$ for both minimum and maximum values of average grain size (i.e., all inclusions fall in either the 1 or 5 size class on our five point scale), whereas maximum evenness $\left(J^{\prime}=1\right)$ is encountered only when inclusions are distributed evenly across all grain size categories, corresponding to the geometric mean of the sand size classes (grain size index $=3$ ).

Significantly, most Formative sherds also follow this curve of sediment maturity, suggesting that clay textures were not strongly modified through the addition of a prepared tempering agent. Only three ceramic samples (one café and two gris) fall well below the arc of maximum evenness (and outside the $95 \%$ confidence interval calculated for the clays) with a larger average grain size than expected given the degree of sorting. Notably, all three outliers also display a clear unimodal grain-size distribution, with a predominance of medium to coarse sand - a pattern potentially signaling the addition of temper. Overall, however, the number of Formative sherds displaying this abnormal pattern is relatively small (8\%).

Given our current evidence, we feel that for the majority of Formative ceramics, the mineral inclusions constitute part of the natural chemical and mineralogical signature and are not a cultural addition. Similarly, we suggest that the range of textural variation encountered within some composition groups represents selection of suitable raw materials from within the same environment, rather than substantial modification of natural clays. These results in turn argue for a fairly straight-forward chemical link between clays and pottery that facilitates provenance assignments.

At the same time, we acknowledge that cultural modification of ceramic pastes remains a challenging issue for provenance determinations and one that merits further investigation (Carpenter and Feinman 1999; Payne 1994:89; Stoltman 1989). Thus, we are currently undertaking petrographic studies of larger samples of clays and sherds in order to assess whether Formative potters tempered particular clays (e.g., with sand derived from the same geological contexts) or refined clays by removing coarse inclusions (for the production of fine wares), and if so, how such cultural practices might have affected the mineral and chemical composition of ceramic pastes.

\subsection{Ceramic Reference Groups}

At least 12 composition groups can be identified within the sample of Late-to-Terminal Formative Oaxacan ceramics. Multimodalities in the major elements sodium and iron divides all samples into three clear groups: one distinctively high in sodium but low in iron, and two groups that share lower sodium values but that differ in iron content (Fig. 3). The high sodium group does not appear to contain distinctive subdivisions; in contrast, the ceramics with lower sodium content can be further subdivided based on multiple major and trace elements to distinguish the remaining reference groups (Fig. 4). These reference groups have been labeled according to their provenance as currently understood and are described below.

3.2.1. Atzompa. The Atzompa reference group ( $\mathrm{N}=99)$ consists largely of cremas (95\%) although a few sherds identified as other wares are compositionally similar to this group. Owing to their characteristic feldspar "temper" (Shepard, 1963, 1967; Thieme, 2001), cremas are strongly enriched in aluminum (Al > 10.5\%) and sodium ( $\mathrm{Na}>$ $2.0 \%)$ relative to other wares, and reduced in most other elements including the transition metals $(\mathrm{Fe}<2.5-3.0 \%)$ 
and rare earth elements (hereafter REE) (Table 1). These ceramics also have low concentrations of the alkali elements cesium and rubidium, but exhibit a broad range of concentration values for barium and potassium. Multimodalities in calcium and barium hint at possible subdivisions; in addition, there is a substantial "halo" group consisting of samples not quite as enriched in sodium as the core group.

The distinctive feldspar inclusions found in crema wares are generally attributed to a spatially restricted outcrop of meta-anorthosite within the Oaxaca Metamorphic Complex, which modern potters from the nearby community of Atzompa still mine as a source of temper (Flannery and Marcus 1994:22-24; Thieme 2001). However, some highly weathered strata of anorthosite provide a clay suitable for hand-forming when used alone, and we suggest that Formative potters were using these clays straight out of the ground. Fired clay tiles formed from the piedmont Minas de Atzompa source (OCS_064) are a close match chemically to crema ceramic pastes (Fig. 5A), suggesting that these clays were not heavily modified or mixed in the manufacture of Formative pottery.

Petrographic analysis verified that these Atzompa clay samples are also quite similar texturally and mineralogically to crema sherds. Both ceramics and clays contain many large, angular to subangular meta-anorthosite fragments and plagioclase grains (Tables 2 and 3), many of which are heavily altered to clay and/or sericite. They also feature an abundance of epidote group minerals, lesser amounts of quartz, biotite, muscovite, hornblende, and opaques, and in a few cases, perthite, pyroxene, and/or garnet. Metamorphism is clearly indicated by the prevalence of epidote group minerals and by deformed plagioclase grains and some sutured feldspar grains.

No additional sources of clay bearing a similar chemical or mineralogical signature were encountered during clay surveys, and provenance is mapped as a small area west of Atzompa (Fig.6A). Several small sites near San Lorenzo Cacaotepec had been previously identified as probable production centers of cremas during Early MA I, based on high densities of the ware and at least one kiln waster, and production of utilitarian crema vessels appears to have continued through Late I (Feinman, 1982:390). During MA II, however, most of the fancier crema types diagnostic to the period were not abundant in these collections (Feinman, 1982: 392). Rather, the numerous large kiln features and associated debris at Monte Albán suggest that production of elite-ware cremas had shifted closer to the administrative core (Markens and Martínez López, 2009), presumably using clays imported from the Atzompa region.

3.2.2. Western Valle Grande (WVG). Two composition groups are associated with the western Valle Grande. WVG$1(\mathrm{~N}=25)$ includes a mix of both café $(72 \%)$ and gris $(20 \%)$ vessels, and the dominance of these coarser ceramics may explain its more variable composition. In contrast, WVG-2 (N=31) contains primarily gris $(90 \%)$ ceramics belonging to a single type (G.29) with a fine, dark paste.

The WVG groups share high concentrations of barium, manganese, and the REE ( $\mathrm{Ce}>80 \mathrm{ppm}$ ) in combination with low cesium content ( $\mathrm{Cs}<2 \mathrm{ppm}$ ) - a signature characteristic of gneiss bedrock and gneiss-derived alluvial deposits primarily located along the western valley (Minc and Sherman, 2011:288-289; Fig. 5B). The two groups differ in their transition metal content, with WVG-1 having much higher concentrations of iron ( $\mathrm{Fe}>6 \%$ ), as well as scandium and chromium. In addition, the WVG-2 group has low total element concentrations overall relative to other reference groups, indicative of significant dilution by silicon (an element not measured directly via INAA), possibly in the form of quartz sand. However, the dilution is not a simple one as WVG-2 shows higher concentrations of barium and substantial heavy REE enrichment, even when the profiles are corrected for dilution effects by matching mean aluminum values.

Petrographic analysis confirms that both WVG-1 and WVG-2 derive from the granitic and gabbroic-dioritic gneisses of the western Valle Grande. Quartz, perthite, and plagioclase predominate, along with biotite, hornblende, pyroxene, opaques, and epidote group minerals; muscovite and garnet are also present though less abundant. Metamorphism is indicated by the presence of epidote group minerals and traces of chlorite, as well as by textures suggestive of metamorphic alteration (e.g., foliation, sutured polycrystalline quartz, bent biotite grains, slightly deformed plagioclase) in some samples. The two groups differ, however, in their quartz:feldspar ratios. In WVG-1 sherds, feldspars (plagioclase, microcline, and other grains difficult to identify due to heavy alteration to clay 
and/or sericite) are more abundant, while WVG-2 sherds have on average higher proportions of quartz and much lower plagioclase counts, a pattern consistent with the dilution issue noted above. Petrographic analysis also confirms two other distinguishing features of the WVG-2 group which led Caso et al. (1967:67; Shepard 1967:481) to initially label the predominant G.29 type as "foreign": amorphous, dark red to reddish-brown ferruginous patches, and abundant, fine opaline particles that appear to be phytoliths. Overall, however, based on the strong similarity with the mineralogy of the Western Valle Grande, we interpret both WVG groups to be local.

Clays with the distinctive high REE signature extend along the western side of the Valle Grande south to Ejutla. Within this region, clays with the highest probabilities of membership in WVG-1 are concentrated between Cuilapan and Zaachila, with secondary areas of lower probability near Yaasuchi and Yatzeche (Fig. 6A). We suggest that the large Formative-era administrative site of Cuilapan is a probable source of WVG-1 ceramics, based on the presence of large kilns and the composition of clays surrounding the site. However, the WVG-1 composition group did not predominate in our collection from the Cuilapan kilns (see below).

In contrast, none of our field-collected clays showed a strong probability of membership in the WVG-2 group, although corrections for the apparent dilution factor yielded low probability matches. The smoothed spatial model identifies a small area adjacent to Yaasuchi as compositionally most similar to the WVG-2 group (Fig. 6A). Given that a large percentage of the WVG-2 ceramics were recovered from Yaasuchi, the production source is likely to be at or near this site. Regional surveys had inferred ceramic production at Yaasuchi based on high densities of gris comb-bottomed bowls (a diagnostic type known as G.12) and a single G.12 waster (Kowalewski et al. 1989); however, excavations targeting the Formative occupation could not confirm early ceramic production at this site (Sherman, 2005).

Finally, we note that the Oaxacan Complex of the western Valle Grande contains a number of intrusive elements, including dikes of pegmatitic composition which contribute to the formation of localized clays and ceramics with extreme values of titanium, hafnium, thorium, and the REE. Our small High Ti-REE group contains likely examples of this phenomenon.

3.2.3. Eastern Valle Grande (EVG). Our EVG groups EVG-1 ( $N=112)$, EVG-2 ( $N=72)$, and EVG-3 $(N=33)$ consist primarily of grís and amarillo ceramics, with a minority of cafés. However, gris vessels predominate in EVG-1 and EVG-3 (ca. 96\%), whereas EVG-2 also has a significant proportion of amarillo vessels (32\%). In fact, $89 \%$ of all amarillo vessels analyzed fall into the EVG-2 subgroup.

For all EVG groups, chemical composition is characterized by high concentrations of calcium (mean ca. $5.3 \%$, range $3.2-14.5 \%$ ) and relatively high concentrations of potassium (ca. $2.5 \%$ ) and rubidium (ca. $100 \mathrm{ppm}$ ), along with intermediate values of the REE and transition metals, a signature consistent with derivation from Ki(lu-ar) bedrock (Fig. 5C). The two main subgroups are distinguished, however, by a clear biomodality in sodium content: EVG-1 has significantly higher concentrations of sodium (mean ca. $1 \%$ ) compared with EVG-2 (mean ca. $0.47 \%$ ), while the groups overlap strongly on most other elements. These chemical differences correspond to a greater sand fraction and a higher proportion of plagiocase inclusions in EVG-1, relative to the finer textures and lower total feldspar count encountered in EVG-2 (Tables 2 and 3). EVG-3 combines generally high sodium values with enriched concentrations of hafnium ( $\mathrm{Hf}>10 \mathrm{ppm}$ ) and titanium (mean ca. $6500 \mathrm{ppm}$ ), along with slight increases in the REE. Like EVG-1, this group has a fairly coarse texture (>20\% sand), with a predominance of quartz (48\%) inclusions. A small number of sherds are of intermediate composition between these and are designated as belonging to the generic EVG group.

Mineral inclusions encountered in EVG ceramics confirm a predominance of sedimentary origins consistent with Ki(lu-ar) bedrock. Mono- and polycrystalline quartz (frequently exhibiting undulose extinction) as well as plagioclase dominate, while perthite and microcline are very common. Many feldspar grains are altered to clay, sericite, or less commonly saussurite. Other minerals consistently present include biotite, muscovite, hornblende, opaques, and calcite. While not entirely restricted to the EVG sherds, calcite is relatively rare in the other compositional groups. In addition, a majority of EVG sherds contain fine- to very fine-grained sedimentary rock 
fragments. At the same time, metamorphic minerals (epidote group and, in a few sherds, chlorite) are common, and other evidence of metamorphism (e.g., deformed plagioclase grains, foliation, suturing of grain boundaries) was observed in a majority of the gris-but not in the amarillo-sherds.

Sedimentary bedrock is widely distributed within the Oaxaca Valley; within the Valle Grande and Ocotlán area, the $\mathrm{Ki}(\mathrm{lu}$-ar) unit extends along the eastern piedmont north of Tilcajete, but also occurs across the valley to the west as a surface cap over metamorphic basement rock under the site of Monte Albán. Throughout this stretch, calcilutite or mudstone strata potentially generate clays similar to the EVG group.

In spite of the prevalence of this parent material, no field-collected clays closely match the high-sodium EVG-1 subgroup. The most promising clays (fine, calcilutite-derived strata immediately upslope of San Agustín de las Juntas) significantly exceed this group in calcium content, while nearby valley-floor clays have only a low probability of group membership. However, the chemical composition of production debris from San Agustín de las Juntas confirms the production of EVG-1 vessels at that site: all the Formative wasters sampled from San Agustín have a high probability of membership in the EVG-1 composition group. In addition, a single Formative G.12 waster from Monte Albán also matches the EVG-1 group, indicating that at least some gris production took place in that center. Given the scarcity of gris kiln wasters encountered in surface surveys of Monte Albán, Blanton (1978:95-96) had suggested that this center was not heavily involved in the production of utilitarian vessels of this ware during the Formative. More recent analyses of 31 single-chambered, rectangular kilns dating to the Terminal Formative (MA II phase) at Monte Albán similarly concluded that while crema and café production debris is abundant, gris wasters are rare in these contexts (Markens and Martínez López, 2009:137). We therefore identify San Agustín as the primary source of EVG-1 gris ceramics, based on the volume of production debris encountered at that site, while acknowledging that some EVG-1 vessels may originate from Monte Albán. Further, although San Agustín had been previously identified as a producer of MA I gray ware (Feinman et al., 1984a:166; Winter, 1984:195), based on the samples in our study, we suggest that the EVG-I source was actively utilized from Rosario through MA II times.

With respect to subgroup EVG-2, two clay samples from the piedmont north of Cerro Tilcajete (OCS_006 and OCS_008) are strikingly similar to this group in composition. In addition, a number of wasters from the modern potting community of Coyotepec have a high probability of membership in EVG-2, as does a single G.12 waster from El Palenque. Our spatial model of clay composition indicates that low-sodium calcareous clays similar to EVG2 extend north of Cerro Tilcajete across a distance of ca. $8 \mathrm{~km}$, suggesting a probable source area between Cerro Tilcajete and Coyotepec (Fig. 6B) although no specific sites in the region have been identified as production loci. Overall, we note something of a north-south gradient in sodium values along the eastern Valle Grande which is useful for establishing provenance.

Clays generically similar to subgroup EVG-3 were recovered from sandy, alluvial deposits in several locations in the valley, but only two locations within the study area closely matched the distinctive high-hafnium signature of this ceramic group (Fig. 6B). Both are located on the alluvium near Cerro Tilcajete, in sites dominated by calcareous sedimentary rock but influenced by significant areas of Precambrian gneiss - a combination that accounts for the EVG signature enriched in hafnium and titanium, and to a lesser extent the REE. Given that EVG-3 sherds are most abundant at the Tilcajete sites, a source near Tilcajete is a likely origin.

3.2.4. Northern Valle Grande (NVG). Composed largely of gris ceramics ( $N=22$ ) from the kilns at Cuilapan, this small group displays a profile quite similar to the EVG-1 group (Fig. $5 \mathrm{C}$ ), but with substantially lower calcium values, and somewhat lower potassium, rubidium, and cesium. In spite of their association with the kiln, none of these sherds are clearly wasters, and their chemical profile is distinct from the clays immediately surrounding Cuilapan, which display a strongly gneissic signature characteristic of the western Valle Grande. Further, the kilns contained a mix of ceramic composition groups, of which a minority did match the local WVG signature. We therefore interpret the kiln contents as garbage swept into a convenient pit left after the kilns were abandoned. Based on similarity to EVG-1 and average high sodium content, we attribute this group to the north-eastern to north-central portion of the Valle Grande, but the specific production locale remains unknown. 
3.2.5. Tilcajete. Our Tilcajete group $(\mathrm{N}=41)$ is intermediate in composition and may represent clays derived from a mix of bedrock parent materials. The group consists entirely of grís ceramics which come overwhelmingly from the Tilcajete sites of El Mogote and El Palenque.

Chemically, this group is most similar to clays and ceramics derived from calcilutite (such as the EVG groups), but with significantly lower sodium and cesium content. It is also distinctively high in chromium $(\mathrm{Cr}>90 \mathrm{ppm})$ relative to iron, and relatively high in tantalum and thorium. Texturally, these sherds are quite fine, with the highest mean percentage of matrix (87\%) of any group, although some sherds are significantly "grittier" than others. Petrographic analysis suggests a possible mix of bedrock associations. Proximity to sedimentary bedrock formations is indicated by fragments of very fine-grained, brownish sedimentary rock (limestone or shale) and/or the presence of calcite in half of the samples analyzed, but traces of metamorphic (epidote group) minerals are also found in some samples, and one sherd contained a coarse fragment with microphenocrysts of quartz or feldspar embedded in a dark, finer-grained groundmass, suggestive of rhyolite/rhyodacite or andesite.

No clays in our current sample can be specifically linked to the Tilcajete group, although its chemical and mineralogical composition is generally consistent with valley clays and it is not obviously foreign. Given the prevalence of these ceramics at El Palenque, it is probable that these ceramics reflect a localized ceramic industry near Cerro Tilcajete. The complex interdigitation of bedrock units near the site - including Cretaceous siltstone, Precambrian gneiss, and localized areas of volcanic ash - could well create a localized clay source with this distinctive composition.

3.2.6. Ocotlán. This group $(\mathrm{N}=29)$ contains a mix of gris $(55 \%)$, café $(31 \%)$, and even a few imitation crema vessels. Chemically, these ceramics are characterized by relatively lower calcium $(\mathrm{Ca}<3 \%)$ and somewhat higher concentrations of cesium (Cs $>7 \mathrm{ppm}$ ), arsenic, and thorium - a signature associated with the influence of volcanic bedrock (particularly andesite) on clay composition (Fig. 5D). At the same time, this group lacks the extreme values of cesium, rubidium, and arsenic which signal the presence of ignimbrite.

Andesite is widespread throughout the eastern and southern arms of the Oaxaca Valley, potentially creating large areas of clay resources with compositions similar to our Ocotlán group (Fig. 6C). Within the Valle Grande-Ocotlán region, clays with the highest probability of group membership concentrate on the alluvium west of Ocotlán de Morelos; however, no Formative-period sites have been identified as potential pottery producers within this area, in part owing to a gap in the settlement surveys (Kowalewski et al., 1989). Chemically similar clays also occur in the eastern branch of the Oaxaca Valley, around the site of Dainzú, which did have a substantial Formative population. Detailed comparisons of our Ocotlán group with Classic-period wasters from Dainzú-Macuilxochitl and Lambityeco (see 3.2.7) suggest substantial differences in calcium and arsenic, along with more subtle differences in the REE. A focus on the most discriminating subset of elements favors Ocotlán as the more likely source of this Formative ceramic group, as does its geographic proximity, but we cannot completely exclude a source area in the eastern valley arm.

Unfortunately, our petrographic data are too limited to confirm the origins of this group, although the two possible source areas are mineralogically distinct: Ocotlán is surrounded almost exclusively by andesite, while the Dainzú area features a mix of andesite, ignimbrite, and calcilutite. Point counts for a single, secure member of the Ocotlán group indicate a predominance of quartz (mono- and polycrystalline), plagioclase and some k-feldspar (with many feldspar grains altered to clay or seritized), biotite, opaques, and epidote group minerals -- i.e., a mineralogy consistent with clays weathered from andesite in the Ocotlán area (e.g., OCS_014). In addition, the lack of obvious glass or ignimbrite fragments (such as those observed in clays from the eastern branch of the valley) suggests that Ocotlán is a more likely region of provenance than is the area around Dainzú.

3.2.7. Non-local groups. In addition to the composition groups originating within the Valle Grande, our ceramic corpus includes a few vessels apparently imported from elsewhere within the Oaxaca Valley. Three different source areas are represented (Fig. 5D). 
Our Central Tlacolula reference group is defined based on Classic-era (Xoo phase) gris ceramic wasters from both Dainzú-Macuilxóchitl and Lambityeco in the eastern (Tlacolula) arm of the valley (Faulseit, 2013; Minc and Pink, 2015). Only five Formative gris vessels in our sample belong to this group; all were recovered from Monte Albán. Chemically, the Central Tlacolula group also represents a volcanic signature; in comparison with the Ocotlán group, it has distinctly higher concentrations of calcium, but lower values for barium, manganese, and some of the REE. Our small petrographic sample also suggests that the Central Tlacolula group sherds are substantially higher in quartz and total feldspars than the Ocotlán group (Table 3). Further, one sample contains polymineralic fragments with silt-sized laths of plagioclase displaying trachytic texture which are reminiscent of andesite fragments evident in field clays sampled near Dainzú (OCS-105).

We also suggest a Southern Etla group, corresponding to Group 1 as defined by Herrera et al., (1999), consisting of Early Formative gray wares from San José Mogote and Tierras Largas in the northern (Etla) branch of the Valley, both of which are situated on sediments ultimately derived from Tertiary conglomerates [Ti(Cg)]. While San José Mogote (the largest site in the valley during the latter Formative) is a likely source, this composition group has an overall profile quite similar to clays and grid points just south of Tierras Largas as well; thus we concur with a generalized provenance on the valley floor in the southern portion of the Etla arm (Herrera et al., 1999:975). Three of our Valle Grande sherds have a significant probability of membership in this group, and five additional samples appear most similar to this group based on their compositional profiles; café ware predominates.

Finally, our High Chromium group represents a small number of café sherds $(\mathrm{N}=4)$ with distinctively high concentrations of iron, scandium, but especially chromium $(\mathrm{Cr}>160)$ and cobalt, that represent clear outliers. Clays with compositional profiles similarly high in the transition metals are associated with conglomerates and sandstones, and include field clays collected west of Tomaltepec (OCS_066, OCS_067, and OCS_096), a known ceramic producing community with evidence of double-chambered firing pits and gris wasters dating to Late MA I (Whalen, 1981, 1988).

In summary, by combining extensive raw material survey with chemical and mineralogical characterization of clays and ceramics and insights from archaeological survey and excavation, we have developed a relatively fine-grained ceramic geography for the Valle Grande-Ocotlán region (Fig. 7). Nine different areas producing ceramics have been identified within the Valle Grande-Ocotlán region during later Middle through Terminal Formative times, along with three non-local production sources from other arms of the valley (SJM-Tierras Largas in the Etla arm, Tomaltepec in the central zone, and Dainzú in the eastern arm). These composition groups account for $>98 \%$ of the ceramic samples analyzed for this critical time period of state formation, a finding that underscores the need to track economic developments - including the rise of specialized production and market exchange - at the local or subvalley level. Unclassified samples include a few obvious outliers, but the majority appears to represent marginal members of groups defined here.

\subsection{Spatial Resolution of Provenance Determinations}

The spatial resolution obtained in mapping ceramic source areas clearly varies according to the scale and distribution of geological parent materials from which clays are derived. In the rare case, the compositional signature can be linked to a very distinctive and localized clay source, which identifies one or a few communities as the likely production center (e.g., Cacaotepec-Atzompa). More commonly, we found either multiple potential source areas or large areas with broadly similar clay composition that approximated the composition of the ceramic group.

For each production source area, we have designated one or more contemporaneous sites as a spatial reference; however, we do not mean to imply that ceramic production was restricted to those communities even in those cases where we cite archaeological evidence of production from a single site. In fact, given the dispersed nature of some compositional signatures, each reference group may well represent multiple communities producing ceramics from slightly different clay resources in their area (Fargher, 2007:323-324). At the same time, most 
production sources identified here were active throughout the Late-to-Terminal Formative sequence, with a span of over 700 years. Thus, the signatures represent long-term utilization of geochemically distinct clays, rather than specific cultural recipes.

The provenance determinations detailed here establish the necessary baseline for monitoring ceramic production and exchange within the valley, and provide a means to track economic interaction in the heartland of the early Zapotec state. In the following sections, we apply these determinations to a re-analysis of the regional organization of ceramic production across the critical time periods of state formation.

\section{REASSESSING THE REGIONAL ORGANIZATION OF CERAMIC PRODUCTION}

Early assessments of craft production in the Valley of Oaxaca utilized data tabulated as part of the comprehensive settlement surveys initiated in the 1970s (Blanton et al., 1982; Feinman, 1982; Kowalewski et al., 1989). These early, innovative studies systematically recorded evidence of pottery manufacture - including production debris (wasters) and unusual concentrations of a specific ceramic type - to characterize the regional organization of this craft through time (Blanton et al., 1999:97; Feinman, 1980, 1982, 1986; Feinman et al., 1984a, 1984b). For the Formative, their primary concern lay with documenting the degree of economic integration that resulted from the emergence of a regional market system, and the influence of this exchange system on the spatial organization of specialized production, such as ceramics. These studies focused on two main metrics - degree of specialization and location of ceramic production - to track changes in market organization.

The regional surveys, however, acknowledged that surface remains represented only a sample of the locations where ceramic production occurred within the valley (Feinman, 1980: 62-63). In order to provide a more comprehensive (if less detailed) view, we re-examine their metrics for specialization and spatial organization using provenance data. To gain the broadest spatial representation for a given time period, we have divided our samples somewhat coarsely into three sequential time periods. These categories include (1) early types and contexts representing the Rosario and Early MA I periods; (2) types that begin in Late MA I but may continue into MA II as well as contexts securely dated to Late MA I; and (3) types and contexts securely dated to MA II.

\subsection{Community Specialization and Production Strategy}

Based on the relative paucity of ceramic production debris recovered on survey, the early analyses of surface remains concluded that pottery was manufactured in a limited number of communities, and was therefore a relatively specialized activity as early as the Middle Formative (Blanton et al., 1999:97; Feinman, 1980, 1982, 1986). Further, surface surveys suggested that each of these sites specialized in the production of a single ware - a level of community specialization that would require market networks to distribute their goods. Since the majority of Early MA I settlements had more than one ware in their surface deposits, it was logical to conclude that "households had access to pottery from more than one production location and that ceramics made in these places were distributed throughout the region" (Feinman et al., 1984a:169).

In the recent historical past, such community specialization in pottery was marked in the Valley of Oaxaca. The potting community of San Bartolo Coyotepec, situated near the beds of fine, calcareous clay of the EVG sources, was the primary source of thin-walled, light-weight water jars (cántaros) up until the 1960s, when these were replaced with plastic vessels. The jars were produced in household workshops and transported by back-pack or donkey cart to local and regional markets, from which they were distributed over the entire valley (van de Velde and van de Velde, 1939). Even today, a degree of product specialization is seen in the cooking vessels manufactured by different potting communities. Atzompa is famous for its coarsely-tempered cooking pots favored for pozole and beans, while San Mateo Mixtepec primarily produces griddles (comales) from coarsegrained piedmont clays (Mindling, 2010). Both of these communities rely on the main produce market in Oaxaca City to distribute their specialized goods throughout the valley.

Not surprisingly, the compositional analyses indicate that Formative ceramics were much more widely produced 
within the valley than suggested by the surface evidence. While the surveys noted only a handful of production sites valley-wide, the trace-element data indicate at least 12 production loci just in our sub-sample of the valley, most of which produced ceramics throughout the time sequence examined here. Further, our analyses confirm that potters from different regions and production sources displayed clear preferences in terms of the specific wares they produced (Fig. 8). Most source areas concentrated on a single ceramic ware, although they clearly had the technological expertise and resources to produce a broader range of vessels. For example, while the EVG sources concentrated on reduced gris vessels, the region also produced oxidized amarillos, and several other source areas combined reduced gris with oxidized café production. Even potters at the Atzompa source - famous for its cremas - utilized the distinctive clays from this locale to produce a small number of gris vessels (as also noted by Shepard at Monte Albán [Caso et al. 1967:24]).

We therefore suggest that the array of goods produced reflects a conscious production strategy that capitalized on the advantages offered by natural resources. That is, the naturally coarse clays derived from metamorphic materials gave potters in the western Valle Grande an edge in the production of café pastes favored for cooking and storage vessels - as is still the case today. In contrast, the high-quality, fine-textured clays weathering from calcilutite gave potters in the eastern Valle Grande an advantage in the production of fine gris ceramics, utilized for thin-walled cantaros and bottles - as continued to be the case at San Bartolo Coyotepec until recently. At the same time, by targeting a narrow subset of consumer demands, this production strategy is heavily reliant on a wider distributional network to deliver these goods to a sufficiently large consumer base for this strategy to be economically viable. Thus, we agree that the existence of a high degree of production specialization in utilitarian goods is convincing evidence for the existence of a market network.

\subsection{Location of Production: Higher-Order vs. Lower-Order Goods}

A second supporting argument of the early regional studies, based on the tenets of economic geography, was that both the location of production and the types of ceramics produced would reflect market forces, specifically, the demand threshold for a specific ware (Blanton et al., 1982:56; Feinman et al., 1984a:166). For Early MA I, their model predicted that high-value ceramics such as the more labor-intensive gris and crema wares would be produced in a central location "that could have serviced the entire regional population" and that was best calculated to reach the highest densities of consumers able to purchase these goods. In contrast, the lower value, utilitarian café vessels would be more widely produced in locations distributed throughout the valley to service the largely rural population. The apparent congruence between predicted production location and demand function during Early and Late MA I was interpreted as reflecting the influence of market forces and, by extension, the emergence of a regionally integrated market system under Monte Albán.

Based on our chemical data, the expectation for the spatial concentration of higher-order goods is not well supported, at least in regards to wares (Fig. 8). Gray ware vessels were more widely produced than previously thought, while café types have a somewhat more limited distribution than had been suggested. However, the economic model proposed by Blanton et al. (1982:56; Feinman 1984a:166-167) focuses on ware largely as a proxy for vessel status; at base, the model implies that production sources closer to Monte Albán produced a greater percentage of higher-status vessels (regardless of ware designation), while producers further removed manufactured more lower-status, utilitarian vessels. Thus, we further examine the provenance data, not simply by ware, but by the relative value or costliness of different ceramic types as indicated by the labor invested in their manufacture.

We first categorized all vessels as either "low cost" or "costly" based on their form, surface finish, and degree of labor investment (e.g., decoration), with the costly category comprising the most elaborate vessels of a given time period. We then examined the distribution of these vessel classes relative to production source through time. The results of the chi-square analysis are presented in Table 4 for production sources represented by at least five vessels in our sample.

We note first, that the more elaborate vessels are clearly over-represented in our study, as they tend to be more 
temporally diagnostic. However, this bias is fairly consistent across wares and producers, except for our sample of cremas, which includes almost exclusively more costly forms. As a result, the statistical significance of the total chisquare values should be treated with caution. Of greater interest here, however, are the cell contributions to the total chi-square, which reflect the over- or under-representation of a vessel class for a given producer.

During the Rosario and Early MA I phases, the overall chi-square value suggests no strong regional patterns in the preferential production of costly vs. low cost utilitarian vessels. All sources appear to have produced a mix of higher and lower cost vessels (Fig. 9a) in proportion to their overall sample size, and no one cell count deviates strongly from the expected value for this period. At the same time, the EVG-1 source emerges as the primary producer of the more elaborate gray ware ceramics, representing $60 \%$ of this category in our sample, as well as a major producer of lower cost vessels (47\%). The location of this most productive source (situated immediately to the east of Monte Albán) is generally consistent with the expectation that production of higher value vessels would be centrally concentrated by Early MA I, but we note that the production of costly vessels was not as spatially restricted as previously thought.

The situation appears to have changed dramatically, however, by the Late MA I phase (Fig. 9b). The CacaotepecAtzompa source - now a major producer of elite crema ceramics - clearly dominated the manufacture of higher class vessels in the central region while their production in other nearby centers declined. The EVG-1 source, for example, shifted its manufacturing efforts to lower cost utilitarian vessels such as thin-walled bottles and cántaros, and the relatively simple G.12 bowls; although more elaborate vessel forms are reported from the site (e.g., bridge-spout jars [Winter, 1984:195]), EVG-1 was not a major supplier of high cost gray types in our sample. Similarly, other producers in the northern half of the Valle Grande (EVG-2, NVG, and WVG-1) are best represented by the more utilitarian vessel forms, such as simple bowls, griddles, and jars. Only in the southern Valle Grande (i.e., the Ocotlán subregion), more than $20 \mathrm{~km}$ from Monte Albán, do we see a balance of costly and low cost utilitarian types being produced. Tilcajete -- which excavation data suggest was economically as well as politically isolated during this phase (see Spencer, 2010; Spencer and Redmond, 2003) -- produced its own suite of elaborate incised and modeled gray ware (e.g., G.17, G.25, G.26) plates, bowls, and fancy bottles, along with a range of standard utilitarian forms.

It is not clear, however, that the concentrated manufacture of higher cost vessels in the core zone reflects market forces, so much as a strong elite interest in regulating access to these sumptuary goods. Certainly during the subsequent MA II period, the construction of large, rectangular kilns for the production of costly crema vessels within the administrative center proper (Markens and Martínez López, 2009) strongly suggests that the elites of Monte Albán were attempting to directly control the production (and hence the distribution) of these goods. The centralized pattern we see in Late MA I may well be the early stages of direct elite involvement. Such a view is consistent with the economic isolation of Tilcajete at this time, interpreted as the result of strong political barriers to trade which prevented elaborate crema ceramics from reaching the southern Valle Grande (Spencer and Redmond, 2001:221-222).

Finally, during MA II, current data suggest that the entire valley was politically integrated under Monte Albán (Blanton et al., 1999; Marcus and Flannery, 1996; cf. Winter 2001:290), although relatively discrete distributions of some ceramic types (Kowalewski et al. 1989: 180-182) hint at persistent divisions whose root causes are not well understood. Within our study area, production of more elaborate vessels again became fairly widespread, but with different production sources appearing to specialize in different costly wares (Fig. 9c). The Atzompa source (with production now concentrated at Monte Albán as noted above) continued to produce elaborate slipped and incised cremas (C.7, C.8, C.11, C.12, C.20), but faced competition from other sites which manufactured fair imitations. The Ocotlán source, for example, produced a number of vessels classified as "cremas" until the chemical signature proved otherwise. Further, along with WVG-1, this source fashioned a well-slipped imitation of the type C.20 but in the café paste (a type known as K.17), while the WVG-2 source specialized in the production of gris vessels (type G.29) whose glossy slip and often red-painted rims imitated the crema types C.6 and C.7 (and in a few cases, C.20). And lastly, the EVG-2 source created a new line of elaborate amarillo vessels (type A.9) with red-painted motifs similar to those typically incised on cremas (Elson and Sherman, 2007). Conversely, other source areas (such as 
EVG-3 and Ocotlán) produced a higher percentage of lower cost vessels, such as simple G.12 and G.21 bowls.

The production locales for the new elite wares rim the Valle Grande during MA II, suggesting widespread demand for these prestige goods, in spite of (or perhaps because of?) the continued control exerted by Monte Albán over crema production at this time. For this same time period, the survey data indicated an increasing concentration of production loci in administrative centers marked by mounded architecture. Blanton et al. (1982:81-84) interpreted this pattern to indicate that political interests rather than economic forces may have dictated the spatial organization of ceramic production, and later speculated that potters in these central locations worked on commission for important lords, as well as producing for market exchange (Blanton et al. 1989:180). In a similar vein, Elson and Sherman (2007) suggest a milieu of heightened competition among local elites during MA II, in which the exchange and display of elaborate ceramics helped solidify status positions and create a network of connections among traditional political rivals of the same social class. The decentralized manufacture of costly ceramics noted here is thus in accord with interpretations that stress the role of local elites in stimulating production of (and possibly control over) high-quality ceramic goods. At the same time, Blanton et al. (1989:180) note the widespread distributions of some utilitarian ceramic types, and suggest that "the regional networks developed by producers such as potmakers are a sign of growth of commercial institutions operating on the regional scale." We concur that product specialization, in which smaller centers were able to produce and effectively market either costly or lower cost goods, provides support for the claim of greater market integration during MA II, at least within the Valle Grande.

\section{CONCLUSIONS}

In summary, although these new results agree in many respects with those presented in older publications, we conclude that our robust geochemical and mineralogical analyses allow for a refinement of some interpretations and an overall advance in our understanding of cultural developments during an important time of change in ancient Oaxaca. Specifically, we concur that the degree of product specialization (i.e., the focus on specific wares) coupled with the broad distribution of wares during Early MA I implies the existence of a supply network consistent with market exchange, although the scale and internal organization of that exchange system remain to be determined. However, our data suggest that by Late MA I, political elites at Monte Albán may have attempted to control production of (and access to) high quality pottery, effectively dampening competition in the site's environs. It is not yet clear how these vessels were then distributed, and whether they moved through the same networks as utilitarian vessels or through an entirely different mechanism, such as elite gift exchange. Finally, by MA II times, demand for elite goods was more generalized and access to market networks perhaps improved as a result of political consolidation - factors that supported increased specialization in either higherorder or less costly utilitarian ceramics. Clearly, the next step is to trace the actual movement of ceramic vessels from producer to consumer in order to document the extent and organization of these ceramic exchanges through time.

\section{DATA ARCHIVING AND AVAILABILITY}

All trace-element data generated as part of this study are being archived through the OSU library system. For data on field clays, see $h t t p: / / i r . l i b r a r y . o r e g o n s t a t e . e d u / x m / u i / h a n d l e / 1957 / 57971$.

\section{ACKNOWLEDGEMENTS}

We gratefully acknowledge Mexico's Instituto Nacional de Antropologia e Historia (INAH) for the opportunity to analyze the clays and ceramics in this study. In particular, we wish to thank Centro INAH Oaxaca personnel Agustín Andrade Cuautle, Eloy J. Pérez Sibaja, Adriana Giraldo Gutierrez, and Julio Lezama Aguilar for facilitating the export process. The regional data assembled here reflect resources pooled among a number of excavators. In addition to 
materials contributed by co-authors, we thank Ronald Faulseit for data on wasters from Dainzú, and Cira Martínez López and Robert Markens for assisting with collections archived at the ex-Convento de Cuilapan. Jeremias Pink helped conduct the second year of clay sampling, and a great team of OSU students worked diligently to prepare all these samples for irradiation. The final manuscript benefitted from comments from Gary Feinman and our anonymous reviewers which encouraged us to clarify our arguments and not overstep our data. Sample collection and analyses were supported in part by grants from the Wenner-Gren Foundation for Anthropological Research and the National Science Foundation (1005945) to PI Leah Minc. 


\section{REFERENCES CITED}

Balkansky, A.K., 1998. Origin and collapse of complex societies in Oaxaca (Mexico): evaluating the era from 1965 to the present. Journal of World Prehistory, 12, 451-93.

Bishop, R.L., Neff, H., 1989. Compositional data analysis in archaeology, in: Allen, R.O. (Ed.), Archaeological Chemistry IV. Advances in Chemistry Series 220, American Chemical Society, Washington, D.C., pp. 57-86.

Blanton, R. E., 1978. Monte Albán: Settlement Patterns at the Ancient Zapotec Capital. Academic Press, New York.

Blanton, R. E., Kowalewski, S., Feinman, G., Appel, J., 1982. Monte Albán's Hinterland, Part I: The Prehispanic Settlement Patterns of the Central and Southern Parts of the Valley of Oaxaca, Mexico. Memoir 15, Museum of Anthropology, University of Michigan, Ann Arbor, MI.

Blanton, R. E., Feinman, G.M., Kowalewski, S.A., Nicholas, L., 1999. Ancient Oaxaca: the Monte Albán State. Cambridge University Press, Cambridge.

Blomster, J.P., Neff, H., Glascock, M.D., 2005. Olmec pottery production and export in ancient Mexico determined through elemental analysis. Science, 307, 1068-1072.

Briggs, I. C., 1974. Machine contouring using minimum curvature. Geophysics, 39, 39-48.

Carpenter, A.J., and Feinman, G.M., 1999. The effects of behaviour on ceramic composition: Implications for the definition of production locations. Journal of Archaeological Science, 26, 783-796.

Caso, A., Bernal, I., Acosta, J., 1967. La Cerámica de Monte Albán. Memorias del Instituto Nacional de Antropología e Historia, 13, Mexico.

Drennan, R.D., 1976. Fábrica San José and Middle Formative Society in the Valley of Oaxaca. Memoir 8, Museum of Anthropology, University of Michigan, Ann Arbor, MI.

Elson, C.M., 2007. Excavations at Cerro Tilcajete: A Monte Albán Il Administrative Center in the Valley of Oaxaca. Memoir 42, Museum of Anthropology, University of Michigan, Ann Arbor, MI.

Elson, C., Sherman, J., 2007. Crema ware and elite power at Monte Albán: Ceramic production and iconography in the Oaxaca Valley, Mexico. Journal of Field Archaeology 32:265-282.

Fargher, L., 2007. A microscopic view of ceramic production: an analysis of thin-sections from Monte Albán. Latin American Antiquity, 18, 313-332.

Faulseit, R.K., 2013. Cerro Danush: Excavations at a Hilltop Community in the Eastern Valley of Oaxaca, Mexico. Memoir 54, Museum of Anthropology, University of Michigan, Ann Arbor, MI.

Feinman, G. M., 1980. The Relationship Between Administrative Organization and Ceramic Production in the Valley of Oaxaca, Mexico. Unpublished Ph.D. dissertation, The City University of New York Graduate Center.

Feinman, G. M., 1982. Patterns of ceramic production and distribution, Periods Early I through V, in: Blanton, R.E., Kowalewski, S.A., Feinman, G.M., Appel, J. (authors), Monte Albán's Hinterland, Part I: The Prehispanic Settlement 
Patterns of the Central and Southern parts of the Valley of Oaxaca, Mexico. Memoir 15, Museum of Anthropology, University of Michigan, Ann Arbor, MI, pp. 181-206.

Feinman, G. M., 1984. Changes in the organization of ceramic production in pre-Hispanic Oaxaca, Mexico: in: Nelson, B. (Ed.), Decoding Prehistoric Ceramics. Southern Illinois University Press, Carbondale, pp. 195-223.

Feinman, G. M., 1986. The emergence of specialized ceramic production in Formative Oaxaca, in: Isaac, B.L. (Ed.), Economic Aspects of Pre-Hispanic Mexico, Research in Economic Anthropology, suppl. 2., pp. 347-73,

Feinman, G. M., Blanton, R., and Kowalewski, S., 1984a. Market system development in the Prehispanic Valley of Oaxaca, Mexico, in: Hirth, K.G. (Ed.), Trade and Exchange in Early Mesoamerica. University of New Mexico Press, Albuquerque, pp. 157-178.

Feinman, G. M., Kowalewski, S., and Blanton, R., 1984b. Modeling ceramic production and organization change in the pre-hispanic Valley of Oaxaca, Mexico, in: van der Leeuw, S.E., Pritchard, A.C. (Ed.s), The Many Dimensions of Pottery: Ceramics in Archaeology and Anthropology. Universiteit van Amsterdam, Amsterdam, pp. 295-338.

Ferrusquía-Villafranca, I., and Ruiz-González, J. , 2007. Sedimental environments and tectonic control of the Valle de Oaxaca graben Miocene continental succession, southeastern Mexico. Paper presented at the Geological Society of America annual meeting, Denver.

Flannery, K. V., and Marcus, J., 1994. Early Formative Pottery of the Valley of Oaxaca. Memoir 27, Museum of Anthropology, University of Michigan, Ann Arbor, MI.

Glascock, M. D., 1992. Characterization of archaeological ceramics at MURR by neutron activation analysis and multivariate statistics, in: Neff, H. (Ed.), Chemical Characterization of Ceramic Pastes in Archaeology. Monographs in World Archaeology 7, Prehistory Press, Madison, pp. 11-26.

Glascock, M. D., 2006. Tables for Neutron Activation Analysis. Research Reactor, University of Missouri, Columbia.

Glascock, M.D., and Neff, H., 2003. Neutron activation analysis and provenance research in archaeology. Measurement Science and Technology, 14, 1516-1526.

Herrera, R. S., Neff, H., Glascock, M. D., 1999. Ceramic patterns, social interaction, and the Olmec: neutron activation analysis of Early Formative pottery in the Oaxaca highlands of Mexico. Journal of Archaeological Science, 26,967-987.

INEGI, 1994, Carta Geológica (1:250,000); sheets E14-09 and E14-12. Instituto Nacional de Estadística Geografía e Informática, Mexico.

Joyce, A., 2010. Mixtecs, Zapotecs, and Chatinos. Wiley-Blackwell, Malden, MA.

Joyce, A. A., Neff, H., Thieme, M. S., Winter, M., Elam, J. M., Workinger, A., 2006. Ceramic production and exchange in Late/Terminal Formative period Oaxaca. Latin American Antiquity, 17, 579-594.

Keppie, J. D., Dostal, J., Cameron, K. L., Solari, L. A., Ortega-Gutiérrez, F., Lopez, R., 2003. Geochronology and geochemistry of Grenvillian igneous suites in the northern Oaxacan Complex, southern Mexico: tectonic implications. Precambrian Research, 120, 365-389.

Keppie, J. D., Dostal, J., Ortega-Gutiérrez, F., and Lopez, R., 2001. A Grenvillian arc on the margin of Amazonia: evidence from the southern Oaxacan Complex, southern Mexico. Precambrian Research, 112, 165-181. 
Kowalewski, S. A., Feinman, G. M., Finsten, L., Blanton, R. E., Nicholas, L., 1989. Monte Albán's Hinterland, Part II: Prehispanic Settlement Patterns in Tlacolula, Etla, and Ocotlán, the Valley of Oaxaca, Mexico. Memoir 23, Museum of Anthropology, University of Michigan, Ann Arbor, MI.

Loaeza-Garcia, J. P., Mendoza-Torres, A., 2007. Carta Geológico-Mineral, Oaxaca de Juárez E14-D47, Oaxaca (1:50,000). Instituto de Geología de la Universidad Autónoma de México and Servicio Geológico Mexicano, Mexico.

Marcus, J., 1998. The peaks and valleys of ancient states: an extension of the dynamic model, in: Feinman, G.M., Marcus, J. (Eds.), Archaic States. School of American Research Press, Santa Fe, pp. 59-94.

Marcus, J., 2008. The archaeological evidence for social evolution. Annual Review of Anthropology, 37, 251-266.

Marcus, J., and Flannery, K.V., 1996. Zapotec Civilization: How Urban Society Evolved in Mexico's Oaxaca Valley. Thames and Hudson, New York.

Markens, R., Martínez López, C., 2009. El sistema de producción ceramica en Monte Albán durante el Preclásico Tardío y el Clásico Tardío, in: Robles García, N.M. (Ed.), Bases de la Complejidad Social en Oaxaca, memoria de la cuarta mesa redonda de Monte Albán., Instituto Nacional de Antropología e Historia, Mexico, D. F., pp. 123-152.

Markens, R., Martínez López, C., Winter, M., n.d. Los hornos de cerámica prehispánicos a través del tiempo en el Valle de Oaxaca: In Pomedio, C., Danneels, A., (Eds.), Memorias del Primer Coloquio de Tecnología Cerámica. Instituto de Investigaciones Antropológicas, Universidad Nacional Autónoma de México, México D.F. (in press).

Martínez-Serrano, R. G., Solís-Pichardo, G., Flores-Márquez, E. L., Macías-Romo, C., Delgado-Durán, J., 2008. Geochemical and Sr-Nd isotopic characterization of the Miocene volcanic events in the Sierra Madre del Sur, central and southeastern Oaxaca, Mexico. Revista Mexicana de Ciencias Geológicas, 25, 1-20.

Minc, L. D., Pink, J.R., 2015. Investigaciones en la Organización Regional de la Producción de Cerámica y el Intercambio en el Valle de Oaxaca durante el Clásico Tardío (550-850 d.C.), Resultados de Análisis Químicos de Arcillas y Cerámicas. Informe final al Consejo de Arqueología del Instituto Nacional de Antropología e Historia, México.

Minc, L. D., Sherman, J. R., 2011. Assessing natural clay composition in the Valley of Oaxaca as a basis for ceramic provenance studies. Archaeometry, 53, 285-328.

Minc, L. D., Sherman, J. R., Elson, C., Spencer, C. S., Redmond, E. M., 2007. "M Glow Blue": archaeometric research at Michigan's Ford Nuclear Reactor. Archaeometry, 49, 215-228.

Mindling, E., 2010. Barro y Fuego: El Arte de la Alfarería en Oaxaca. Editorial Arte Oaxaca, Mexico.

Mora, C. I., Valley, J. W., Ortega-Gutiérrez, F., 1986. The temperature and pressure conditions of the Grenville-age granulite facies metamorphism of the Oaxacan Complex, Southern Mexico, Universidad Nacional Autónomo de México. Revista del Instituto Geológico, 6, 222-242.

Neff, H., Bishop, R. L., and Sayre, E. V., 1988. A simulation approach to the problem of tempering in compositional studies of archaeological ceramics, Journal of Archaeological Science, 15, 159-172.

Neff, H., Bishop, R. L., and Sayre, E. V., 1989. More observations on the problem of tempering in compositional studies of archaeological ceramics, Journal of Archaeological Science, 16, 57-69.

Neff, H., 2002. Quantitative techniques for analyzing ceramic compositional data, in: ed. Glowacki, D.M., Neff, H. 
(Eds.), Ceramic Production and Circulation in the Greater Southwest: Source Determination by INAA and Complementary Mineralogical Investigations. Monograph 44, The Cotsen Institute, Los Angeles, pp. 15-36.

Ortega-Gutiérrez, F., 1981. Metamorphic belts of southern Mexico and their tectonic significance. Geofisica Internacional, 20, 177-202.

Ortega-Obregon, C., Keppie, J. D., Solari, L. A., Ortega-Gutiérrez, F., Dostal, J., Lopez, R., Ortega-Rivera, A., Lee, J. W. K., 2003. Geochronology and geochemistry of the 917 Ma, calc-alkaline Etla granitoid pluton (Oaxaca, southern Mexico): evidence of post-Grenvillian subduction along the northern margin of Amazonia. International Geology Review, 45, 596-610.

Payne, W. O., 1994. The raw materials and pottery-making techniques of Early Formative Oaxaca: an introduction. In Flannery, K.V., Marcus, J. (Authors), Early Formative Pottery of the Valley of Oaxaca. Memoir 27, Museum of Anthropology, University of Michigan, Ann Arbor, MI, pp. 7-20.

Pielou, E. C., 1977. Mathematical Ecology, Wiley, New York.

Quinn, P. S., 2013. Ceramic Petrography: The Interpretation of Archaeological Pottery \& Related Artefacts in Thin Section, Archaeopress, Oxford.

Redmond, E., G. Harbottle, 1983. Neutron-activation analysis of ceramics from the Valley of Oaxaca and the Cuicatlan Canada, in: Redmond, E. (Author), Fuego y Sangre: Early Zapotec Imperialism in the Cuicatlan Canada, Oaxaca. Memoir 16, Museum of Anthropology, University of Michigan, Ann Arbor, MI, pp. 185-205.

Rice, P. M., 1987. Pottery Analysis: A Sourcebook, University of Chicago Press, Chicago.

Shepard, A., 1963. Beginnings of ceramic industrialization: an example from the Oaxaca Valley, in: Shepherd, A. (Ed.), Notes from a Ceramic Laboratory 2. Carnegie Institution, Washington, D.C., pp. 1-24.

Shepard, A. O., 1965. Ceramics for the Archaeologist, Carnegie Institution of Washington Publication 609, Washington, D.C..

Shepard, A., 1967. Preliminary notes on the paste composition of Monte Albán pottery, in: Caso, A., Bernal, I., Acosta, J. (Authors), La Cerámica de Monte Albán. Memorias del Instituto Nacional de Antropología e Historia, Mexico, pp. 477-484.

Sherman, R. J., 2005. Settlement heterogeneity in the Zapotec state: a view from Yaasuchi, Oaxaca, Mexico. unpublished Ph.D. dissertation, University of Michigan, Ann Arbor.

Sherman, R.J., Balkansky, A.K., Spencer, C.S., Nicholls, B.D., 2010. Expansionary dynamics of the nascent Monte Albán state. Journal of Anthropological Archaeology, 29, 278-301.

Sherman, R.J., Minc, L.D., 2105. Assessing Ceramic Production and Exchange in the Early Monte Albán State (Oaxaca, Mexico). Paper presented at the 80th Annual Meeting, Society for American Archaeology, San Francisco, April, 2015.

Smith, W. H. F., Wessel, P., 1990. Gridding with continuous curvature splines in tension. Geophysics, 55, 293-205.

Spencer, C.S., 2010. Territorial expansion and primary state formation. Proceedings of the National Academy of Sciences, 107, 7119-26. 
Spencer, C.S.,Redmond, E.M., 2001. Multilevel selection and political evolution in the Valley of Oaxaca, 500-100 B.C.. Journal of Anthropological Archaeology, 20, 195-229.

Spencer, C. S., Redmond, E. M., 2003. Militarism, resistance, and early state development in Oaxaca, Mexico. Social Evolution and History, 2(1), 25-70.

Spencer, C.S., Redmond, E.M., 2004. Primary state formation in Mesoamerica. Annual Review of Anthropology, 33, 173-99.

Spencer, C.S., and Redmond, E.M., 2006, Resistance strategies and early state formation in Oaxaca, Mexico, in Elson, C.M., Covey. R.A. (Eds.), Intermediate Elites in Pre-Columbian States and Empires. University of Arizona Press, Tucson, pp. 21-43.

Sterba, J. H., Mommsen, H., Steinhouser, G., and Bichler, M., 2009. The influence of different tempers on the composition of pottery, Journal of Archaeological Science, 36(7), 1582-1589.

Stoltman, J. B., 1989. A quantitative approach to the petrographic analysis of ceramic thin sections. American Antiquity, 54, 147-160.

Stoltman, J. B., 1991. Ceramic petrography as a technique for documenting cultural interaction: an example from the Upper Mississippi Valley. American Antiquity, 56, 103-120.

Stoltman, J.B., J. Marcus, K. V. Flannery, J. H. Burton, R. G. Moyle, 2005. Petrographic evidence shows that pottery exchange between the Olmec and their neighbors was two-way. Proceedings of the National Academy of Sciences, $102,11213-11218$.

Thieme, M. S., 2001. Continuity of ceramic production: examination and analysis of clay materials from Santa María Atzompa, in: Robles García, N.M. (Ed.). Procesos de Cambio y Conceptualización del Tiempo, memoria de la primera mesa redonda de Monte Albán. Instituto Nacional de Antropología e Historia, Mexico, D. F., pp. 339-349.

Urrutia-Fucugauchi, J., and Ferrusquía-Villafranca, I., 2001. Paleomagnetic results for the Middle-Miocene continental Suchilquitongo Formation, Valley of Oaxaca, southeastern Mexico. Geofísica Internacional, 40, 191205.

Van de Velde, P., and H.R. Van de Velde, 1939. The Black Pottery of Coyotepec, Oaxaca, Mexico. Southwest Museum Papers No. 13, Los Angeles, CA.

Whalen, M. E., 1981. Excavations at Santo Domingo Tomaltepec: Evolution of a Formative Community in the Valley of Oaxaca, Mexico. Memoir 12, Museum of Anthropology, University of Michigan, Ann Arbor, MI.

Whalen, M. E., 1988. Small community organization during the Late Formative period in Oaxaca, Mexico. Journal of Field Archaeology 15(3), 291-306.

Winter, M., 1976. Cerámica de la fase Rosario encontrada en dos pozos tronco-cónicos en el sitio de Tierras Largas, Valle de Oaxaca, México. Centro Regional de Oaxaca, INAH.

Winter, M., 1984. Exchange in Formative Highland Oaxaca, in: Hirth, K.G. (Ed.), Trade and Exchange in Early Mesoamerica. University of New Mexico Press, Albuquerque, pp. 179-214.

Winter, M., 2001. Palacios, Templos y 1,300 Años de Vida Urbana en Monte Albán, in Ciudad Ruiz, A., Iglesias Ponce de León, M.J., Martínez Martínez, M.C. (Eds.), Reconstruyendo la ciudad maya: El urbanismo en las 
sociedades antiguas. Sociedad Española de Estudios Maya 6, Madrid, pp. 277-301. 
Figure 1. Geological map of the Valley of Oaxaca, Mexico showing major bedrock units influencing clay composition, as well as clay sampling locations, and major sites mentioned in the text. Dashed line marks approximate boundary of Oaxaca settlement surveys. Inset rectangle indicates spatial focus of this study.

Figure 2. Bivariate plot of average grain-size versus J' (evenness of sand-size fraction) displaying a natural arc of sediment maturity. Clays (open symbols) and ceramics (solid symbols) display a similar range of textures from coarse, poorly sorted to fine, well sorted. Dashed lines indicate $95 \%$ confidence interval for the clays.

Figure 3. Major subdivisions within Formative ceramics on bivariate plot of sodium and iron.

Figure 4. Major subdivisions within Formative ceramics on bivariate plot of chromium and scandium.

Figure 5. Normalized compositional profiles for the major Formative ceramic groups.

A. Atzompa ceramics relative to clays derived from gneiss [pc(An)];

B. WVG-1 and WVG-2 relative to clays derived from gneiss $[\mathrm{pC}(\mathrm{Gn})]$;

C. EVG relative to clays derived from calcilutite [Ki(lu-ar)]; and D. Ocotlán and Dainzú relative to clays derived from andesite $[\mathrm{Tom}(\mathrm{A})]$.

Figure 6. Areas with clays similar to Formative ceramic composition groups, illustrating the distribution of ceramic production and the spatial resolution obtained in provenance determinations.

A. Atzompa and the WVG ceramic groups. The Atzompa group (shown in black) is clearly associated with meta-anorthosite SW of the modern community of Atzompa, although these clays were also imported to Monte Albán. WVG-1 (light grey) originates from the Cuilapan area, while WVG-2 (dark grey) comes from near Yaasuchi.

B. The main EVG ceramic composition groups. EVG-1 (dark grey) was largely produced at San Agustín de las Juntas, while EVG-2 (black) originates from the Coyotepec- Cerro Tilcajete area. EVG-3 (light grey) matches alluvial clays in two areas adjacent to Cerro Tilcajete.

C. Clays of andesitic derivation matching the Ocotlán composition group (light gray); of these, the area immediately west of Ocotlán is the most likely source.

D. Probable sources of ceramics from outside the Valle Grande, including the Central Tlacolula group (black), the S. Etla composition group (dark gray), and the High Cr group tentatively attributed to Tomaltepec (light gray).

Figure 7. Schematic overview of source area locations for Middle to Terminal Formative ceramics.

Figure 8. Wares as a percentage of total sample from each production source.

Figure 9. Costly vs. low-cost utilitarian vessels as a percentage of total sample from each production source through time. (a) Rosario - Early MA I; (b) Late MA I - MA II; (c) MA II. 



\section{TABLES}

1. Average chemical composition of Oaxacan ceramic composition groups.

2. Textural data for Formative ceramic composition groups.

3. Petrography of Formative ceramic composition groups.

4. Chi-square analysis of vessel status vs composition group. 


\section{Figure 1}

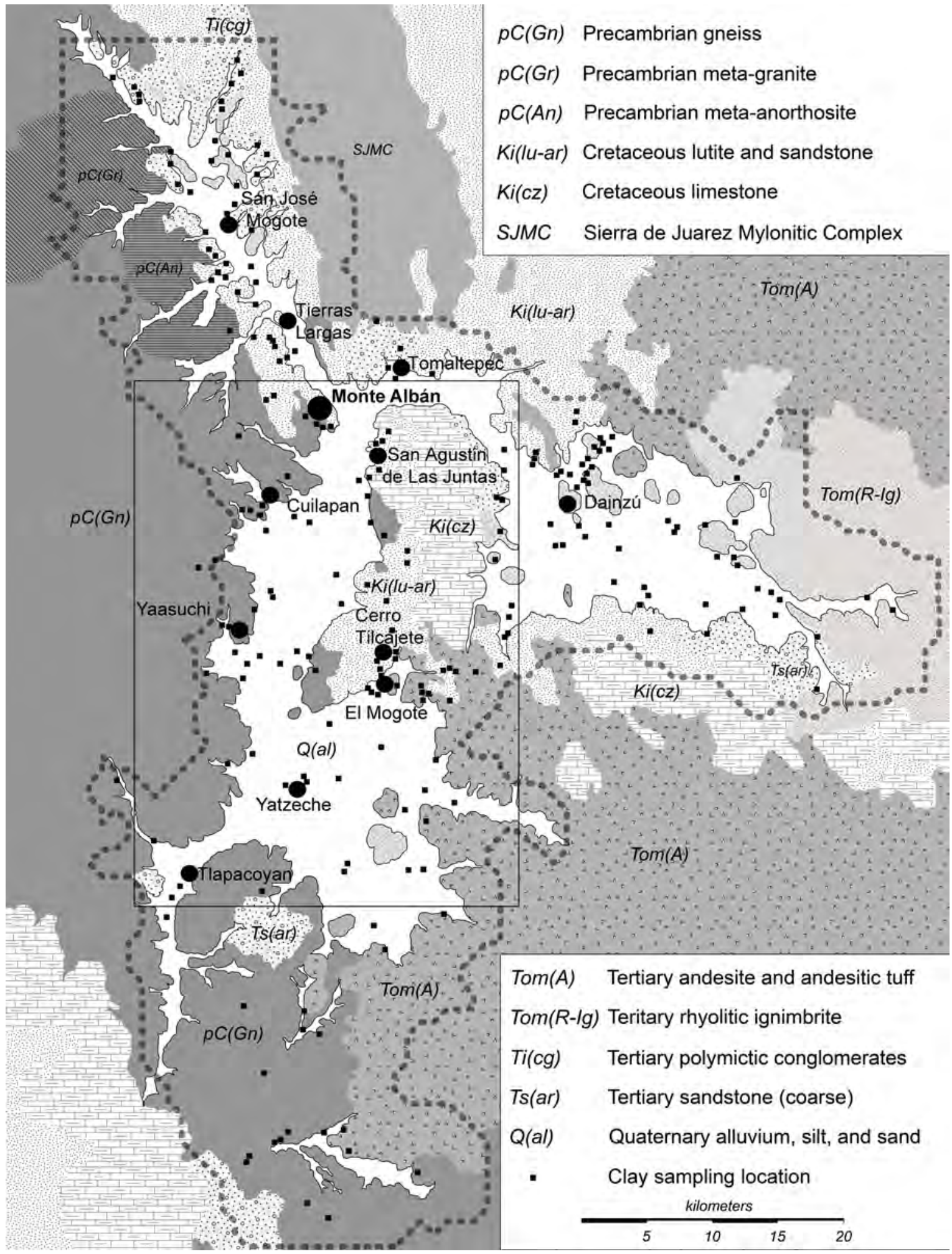




\section{Figure 2}

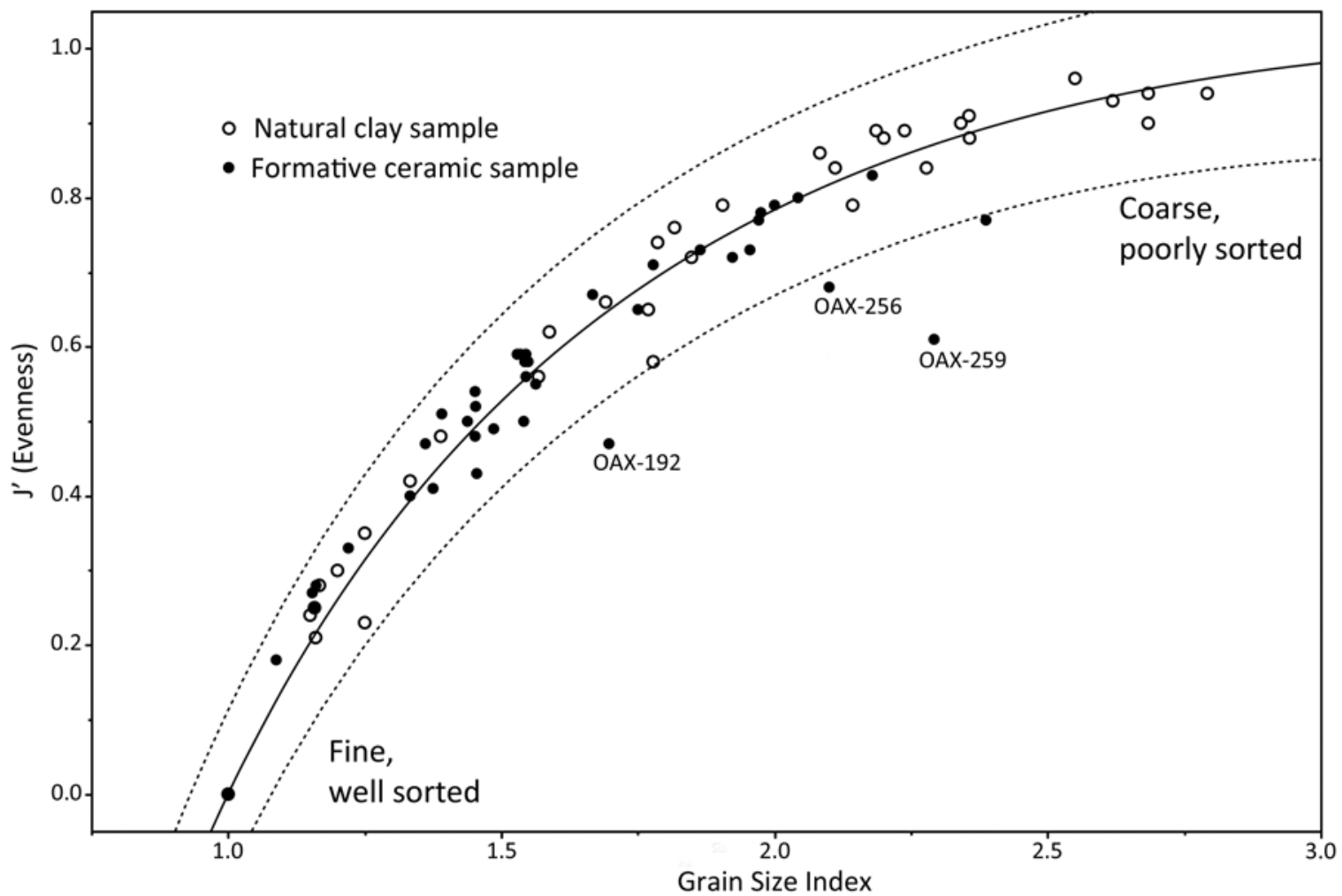




\section{Figure 3}

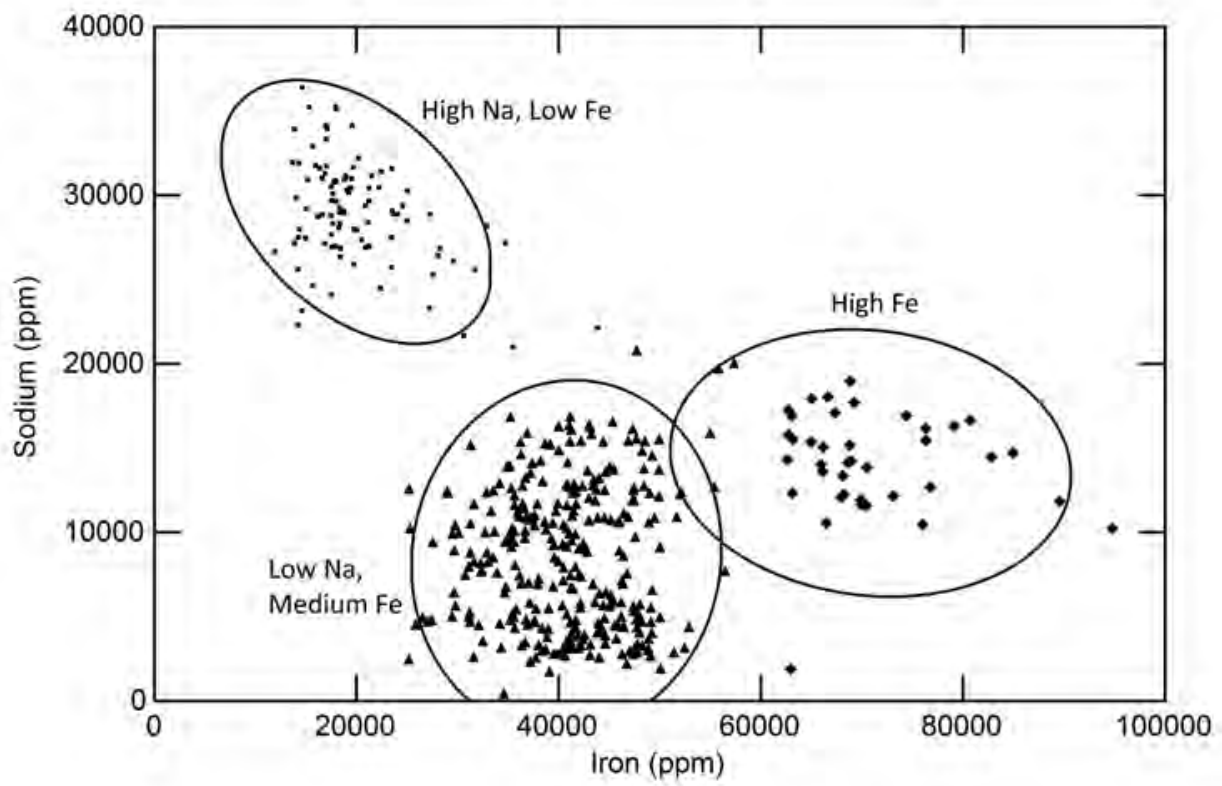




\section{Figure 4}

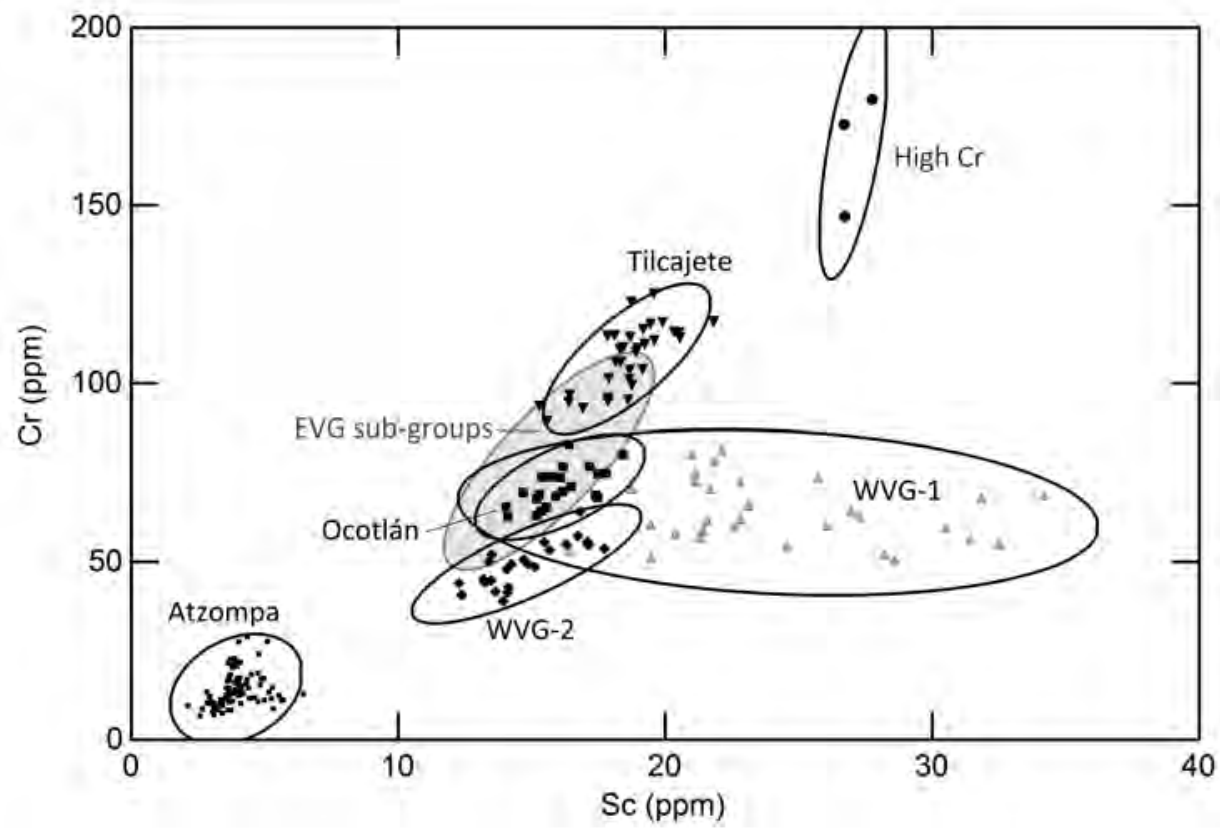




\section{Figure 5}
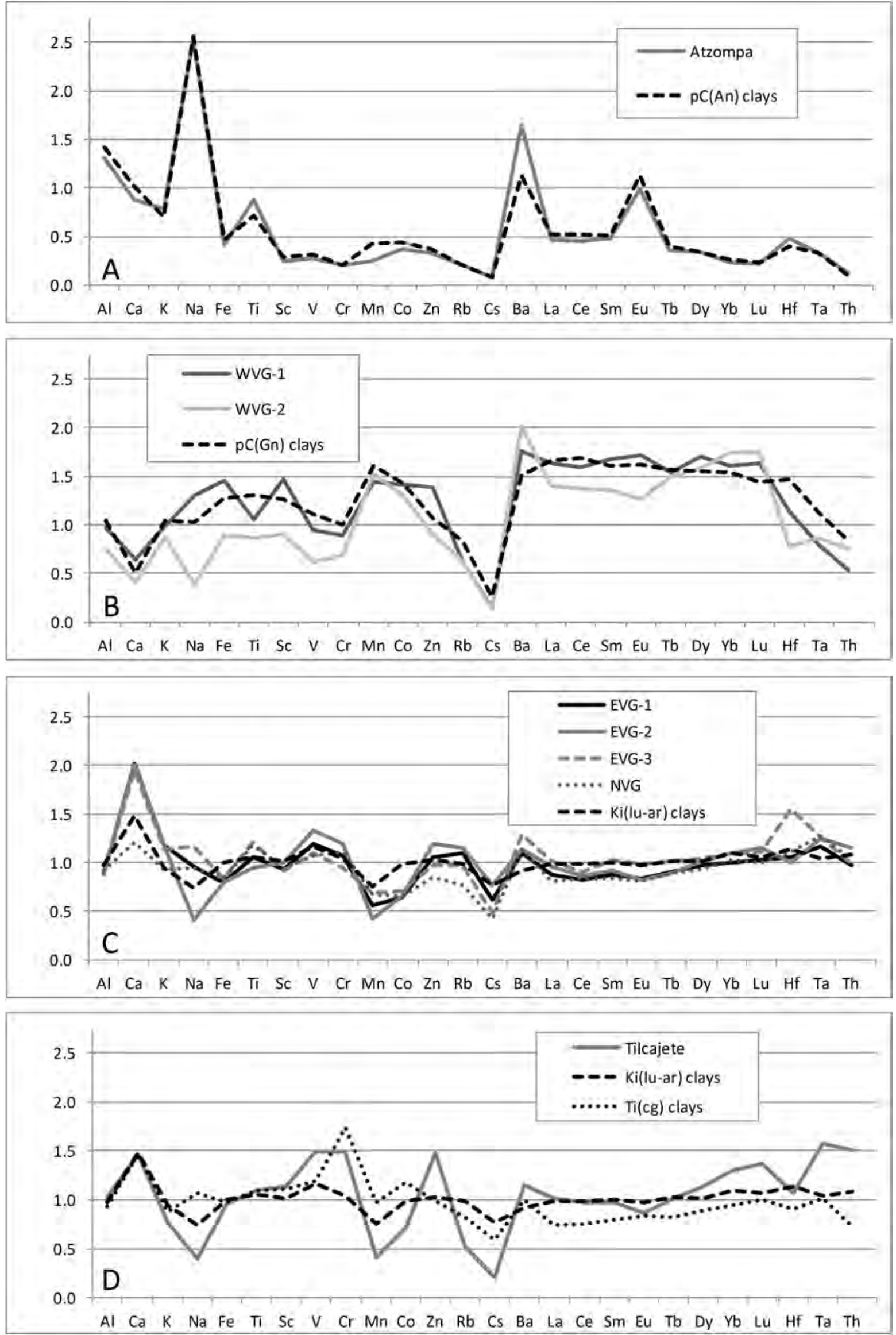


\section{Figure 6}
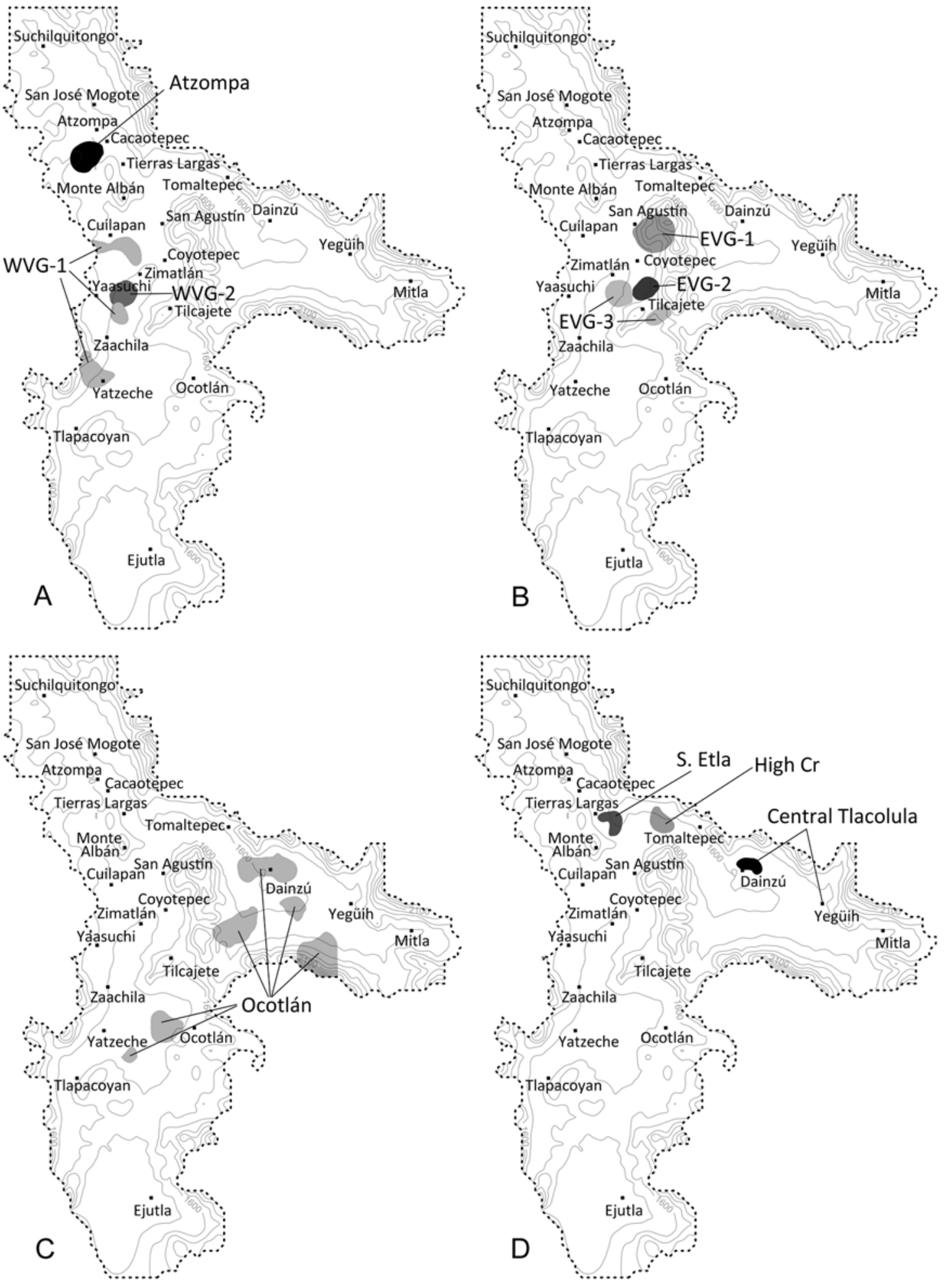


\section{Figure 7}

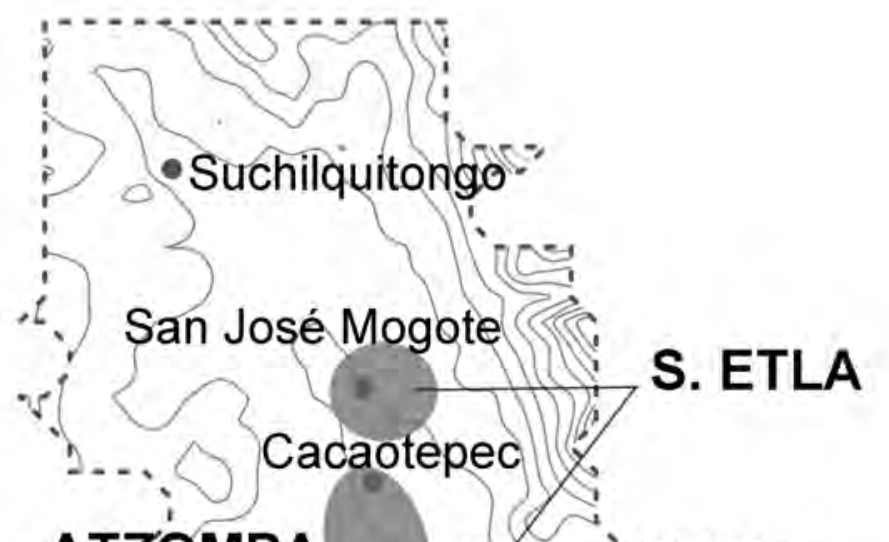

\section{ATZZOMPA \\ Tierras Largas -}

Tomaltepec.

HIGH CR

Monte Albán

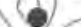

\section{WVG-1 \\ Cuilapan}

NVG

EVG-1

(.....

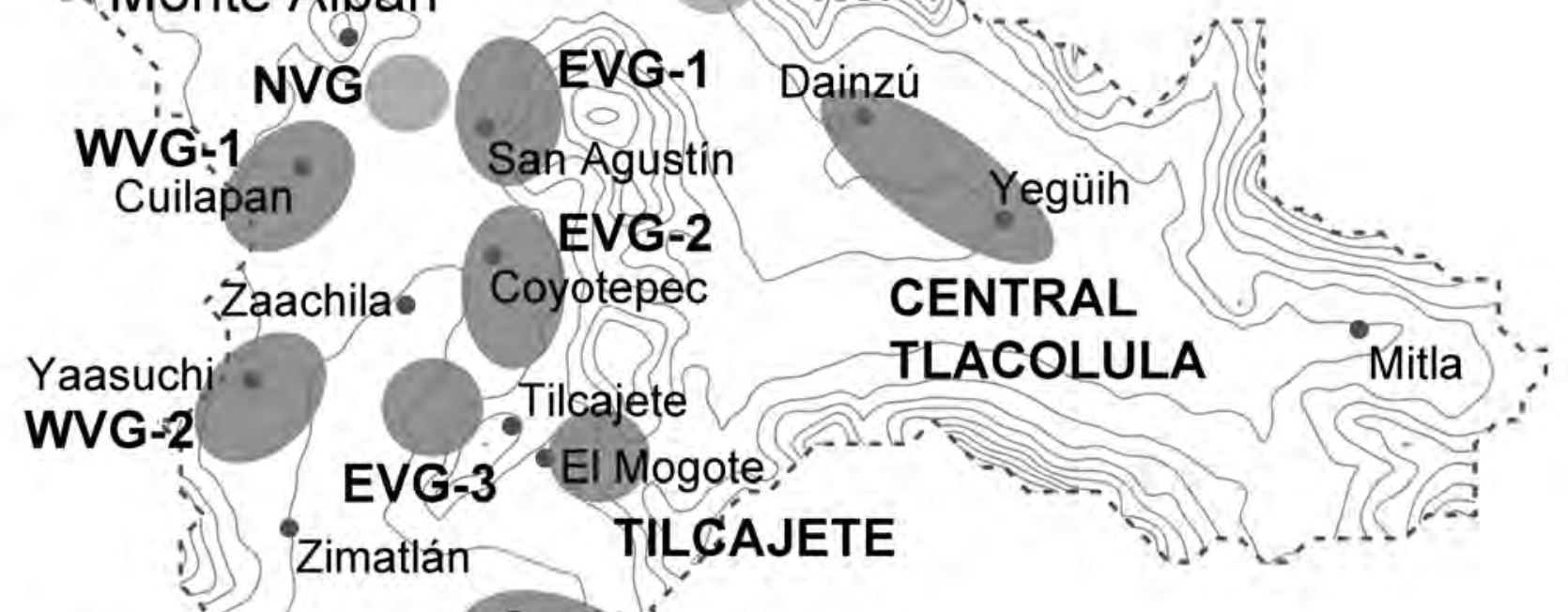

Waasuchi Tilcajete

1) Zimatlán

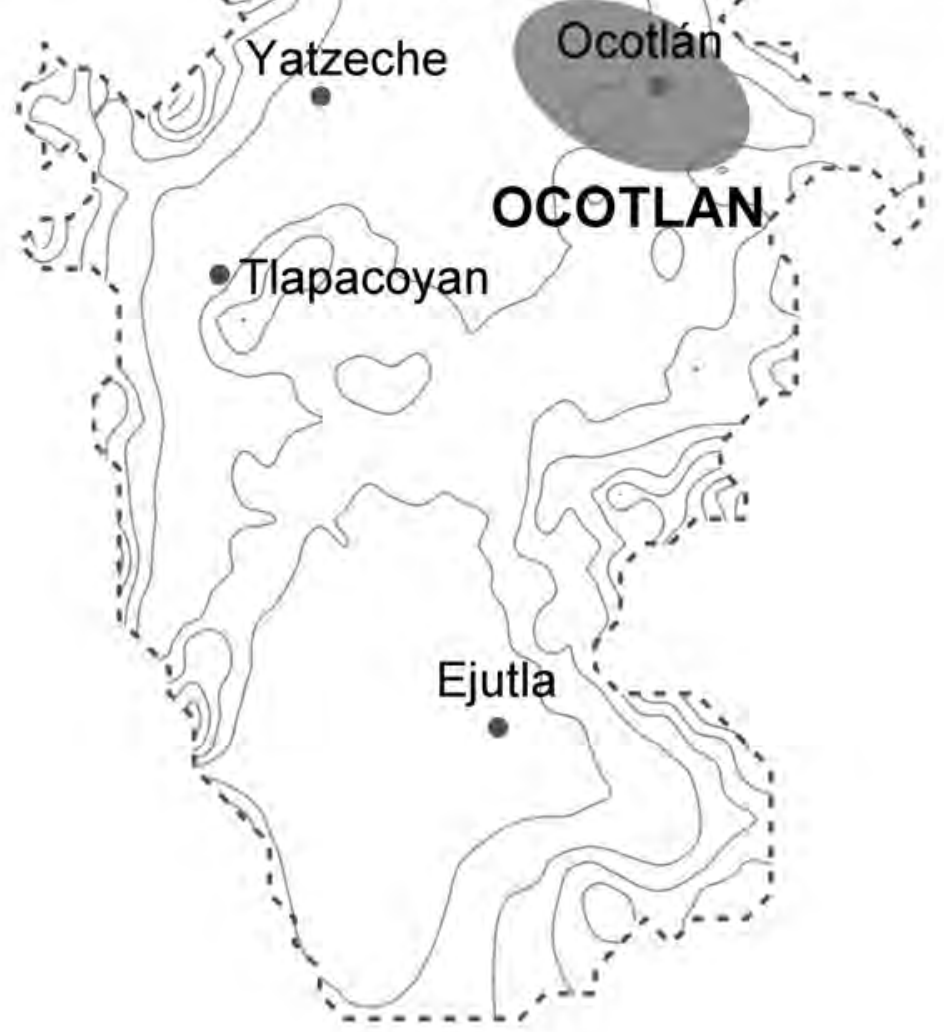




\section{Figure 8}
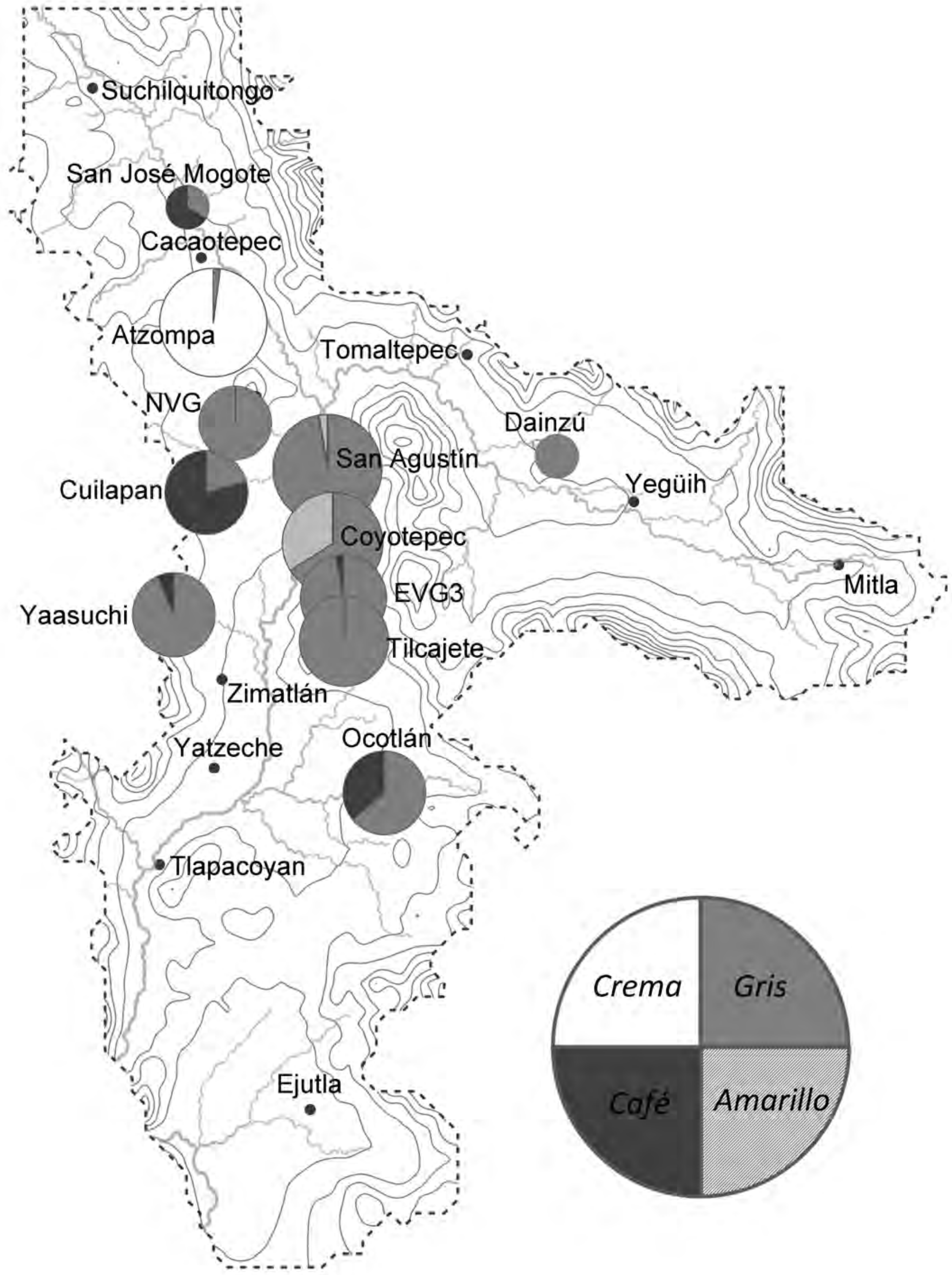


\section{Figure 9}

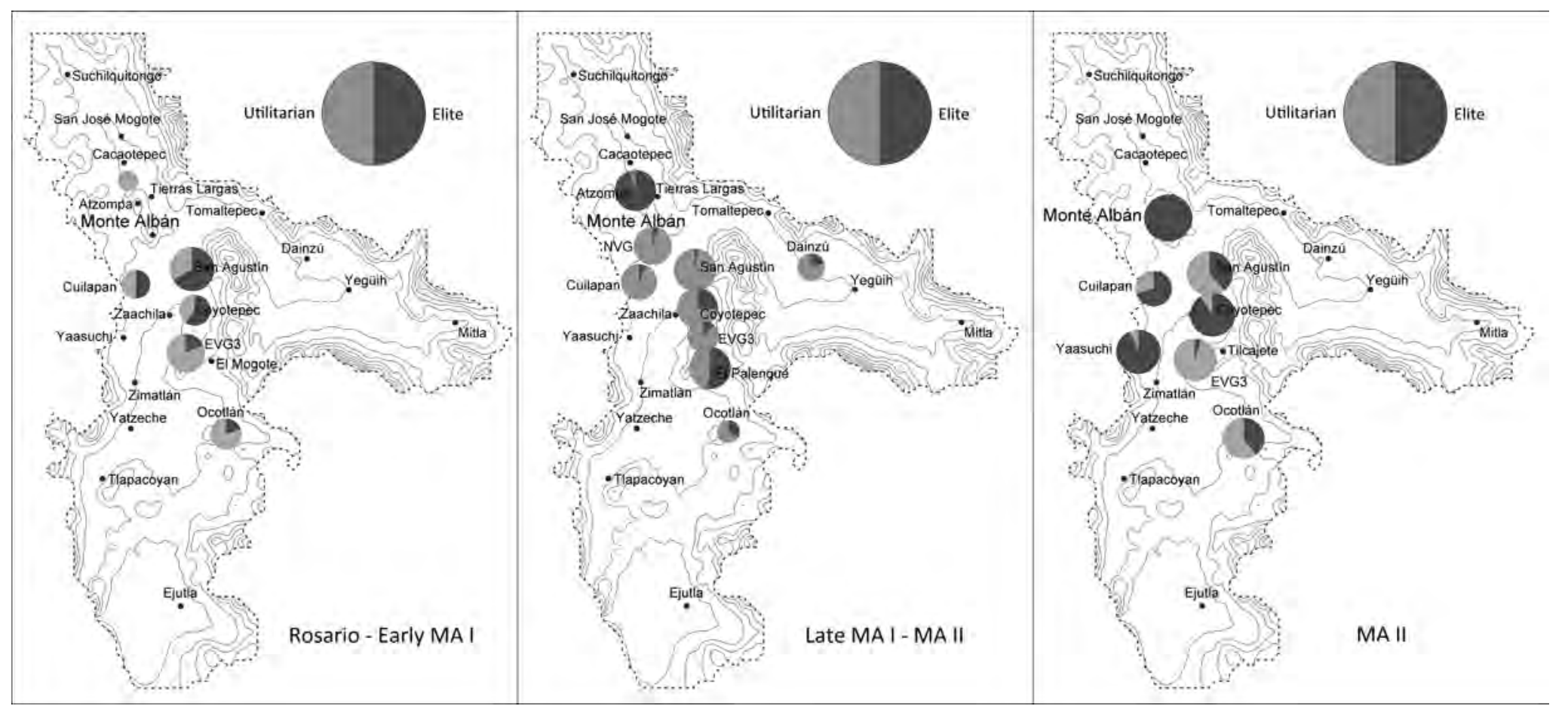


Table 1. Average chemical composition of Oaxacan ceramic composition groups.

\begin{tabular}{|c|c|c|c|c|c|c|c|c|c|c|}
\hline \multirow[b]{2}{*}{ Element } & \multicolumn{2}{|c|}{ Atzompa (N=97) } & \multicolumn{2}{|c|}{ WVG-1 (N=25) } & \multicolumn{2}{|c|}{ WVG-2 (N=31) } & \multicolumn{2}{|c|}{ High Ti-REE ( $N=3)$} & \multicolumn{2}{|c|}{ EVG-1 ( $\mathrm{N}=111)$} \\
\hline & Mean & S.D. & Mean & S.D. & Mean & S.D. & Mean & S.D. & Mean & S.D. \\
\hline $\mathrm{Al}(\%)$ & 12.10 & 0.66 & 8.96 & 0.46 & 6.95 & 0.59 & 8.37 & 0.20 & 8.29 & 0.63 \\
\hline Ca (\%) & 2.70 & 0.84 & 1.92 & 0.30 & 1.25 & 0.41 & 2.21 & 0.85 & 5.82 & 1.65 \\
\hline K (\%) & 1.69 & 0.37 & 2.13 & 0.43 & 1.87 & 0.35 & 1.98 & 0.13 & 2.53 & 0.34 \\
\hline $\mathrm{Na}(\%)$ & 2.82 & 0.32 & 1.43 & 0.21 & 0.42 & 0.10 & 1.20 & 0.11 & 1.03 & 0.22 \\
\hline Fe (\%) & 2.00 & 0.54 & 7.27 & 1.08 & 4.23 & 0.43 & 6.97 & 0.14 & 3.72 & 0.45 \\
\hline $\mathrm{Ti}(\%)$ & 0.47 & 0.21 & 0.58 & 0.16 & 0.46 & 0.07 & 1.97 & 0.23 & 0.55 & 0.09 \\
\hline Sc & 4.05 & 1.10 & 25.41 & 4.64 & 14.70 & 1.62 & 17.65 & 0.15 & 15.28 & 1.58 \\
\hline V & 36.78 & 15.07 & 123.06 & 18.60 & 80.74 & 12.71 & 130.90 & 10.47 & 156.10 & 25.59 \\
\hline $\mathrm{Cr}$ & 14.47 & 4.99 & 60.20 & 8.41 & 48.58 & 6.34 & 17.57 & 2.55 & 76.83 & 11.69 \\
\hline $\mathrm{Mn}$ & 231.33 & 117.98 & 1308.06 & 381.55 & 1383.43 & 324.18 & 1483.81 & 858.37 & 493.53 & 122.79 \\
\hline Co & 6.83 & 2.93 & 25.24 & 3.18 & 22.80 & 3.48 & 17.97 & 1.43 & 11.05 & 1.74 \\
\hline $\mathrm{Zn}$ & 37.83 & 9.41 & 151.39 & 50.55 & 101.23 & 16.47 & 157.71 & 9.45 & 118.07 & 24.87 \\
\hline As & 2.09 & 1.92 & 5.43 & 2.19 & 3.53 & 1.50 & 4.57 & 3.09 & 7.17 & 4.18 \\
\hline $\mathrm{Rb}$ & 18.72 & 4.99 & 53.84 & 17.88 & 58.15 & 8.36 & 30.98 & 7.27 & 101.86 & 15.32 \\
\hline Cs & 0.82 & 0.30 & 0.85 & 0.33 & 1.23 & 0.34 & 1.11 & 0.30 & 6.08 & 1.25 \\
\hline $\mathrm{Ba}$ & 1244.16 & 351.04 & 1438.08 & 408.63 & 1478.09 & 453.28 & 1487.33 & 359.21 & 848.26 & 283.00 \\
\hline La & 16.57 & 3.18 & 60.88 & 11.10 & 50.52 & 5.89 & 93.70 & 1.84 & 31.27 & 3.33 \\
\hline $\mathrm{Ce}$ & 34.33 & 6.49 & 126.78 & 28.24 & 103.08 & 15.44 & 190.44 & 5.09 & 62.10 & 6.68 \\
\hline Sm & 3.65 & 0.95 & 13.58 & 2.25 & 10.63 & 1.59 & 23.11 & 0.73 & 6.64 & 0.71 \\
\hline $\mathrm{Eu}$ & 1.82 & 0.28 & 3.33 & 0.69 & 2.34 & 0.32 & 5.25 & 0.23 & 1.53 & 0.14 \\
\hline $\mathrm{Tb}$ & 0.35 & 0.11 & 1.66 & 0.29 & 1.49 & 0.22 & 2.21 & 0.09 & 0.89 & 0.16 \\
\hline Dy & 1.77 & 0.52 & 9.39 & 1.23 & 8.34 & 1.10 & 11.03 & 0.17 & 5.08 & 0.67 \\
\hline $\mathrm{Yb}$ & 0.66 & 0.20 & 4.78 & 0.55 & 4.93 & 0.60 & 4.53 & 0.21 & 2.81 & 0.32 \\
\hline $\mathrm{Lu}$ & 0.08 & 0.03 & 0.66 & 0.07 & 0.67 & 0.09 & 0.55 & 0.02 & 0.40 & 0.05 \\
\hline $\mathrm{Hf}$ & 3.25 & 1.68 & 9.29 & 4.81 & 4.94 & 0.95 & 17.10 & 0.73 & 6.56 & 1.38 \\
\hline Ta & 0.21 & 0.09 & 0.53 & 0.18 & 0.54 & 0.07 & 1.34 & 0.09 & 0.75 & 0.12 \\
\hline Th & 0.81 & 0.44 & 3.47 & 1.35 & 5.69 & 2.36 & 1.64 & 0.29 & 6.87 & 1.17 \\
\hline
\end{tabular}


Table 2. Textural data for Formative ceramic composition groups.

\begin{tabular}{|c|c|c|c|c|c|c|c|c|c|c|c|c|c|c|c|}
\hline \multirow[b]{2}{*}{ Sample } & \multirow{2}{*}{$\begin{array}{l}\text { Comp. } \\
\text { group }\end{array}$} & \multirow[b]{2}{*}{ Points } & \multirow[b]{2}{*}{ Voids } & \multirow[b]{2}{*}{ Matrix } & \multirow[b]{2}{*}{$\%$} & \multirow[b]{2}{*}{ Silt } & \multirow[b]{2}{*}{$\%$} & \multirow[b]{2}{*}{ Sand } & \multirow[b]{2}{*}{$\%$} & \multicolumn{4}{|c|}{ Sand size } & \multirow[b]{2}{*}{ Gravel } & \multirow{2}{*}{$\begin{array}{c}\text { Size } \\
\text { index }\end{array}$} \\
\hline & & & & & & & & & & Fine & Med & Coarse & VC & & \\
\hline CTL-063 & Atzompa & 149 & 3 & 90 & 60.4 & 9 & 6.0 & 47 & 31.5 & 21 & 11 & 7 & 8 & 0 & 2.0 \\
\hline OAX-010 & Atzompa & 130 & 6 & 87 & 66.9 & 9 & 6.9 & 28 & 21.5 & 10 & 8 & 5 & 5 & 0 & 2.2 \\
\hline \multirow[t]{2}{*}{ OAX-045 } & Atzompa & 268 & 11 & 170 & 63.4 & 12 & 4.5 & 75 & 28.0 & 12 & 28 & 29 & 6 & 0 & 2.4 \\
\hline & Mean & & & & 63.6 & & 5.8 & & 27.0 & & & & & & 2.2 \\
\hline MA-028 & WVG-1 & 206 & 5 & 180 & 87.4 & 4 & 1.9 & 17 & 8.3 & 11 & 4 & 1 & 1 & 0 & 1.5 \\
\hline MA-045 & WVG-1 & 184 & 6 & 127 & 69.0 & 16 & 8.7 & 35 & 19.0 & 20 & 14 & 0 & 1 & 0 & 1.5 \\
\hline OAX-040 & WVG-1 & 201 & 3 & 152 & 75.6 & 15 & 7.5 & 31 & 15.4 & 27 & 3 & 1 & 0 & 0 & 1.2 \\
\hline OAX-147 & WVG-1 & 191 & 19 & 100 & 52.4 & 19 & 9.9 & 53 & 27.7 & 34 & 16 & 1 & 2 & 0 & 1.5 \\
\hline OAX-226 & WVG-1 & 173 & 22 & 108 & 62.4 & 8 & 4.6 & 35 & 20.2 & 20 & 11 & 4 & 0 & 0 & 1.5 \\
\hline \multirow[t]{2}{*}{ OAX-259 } & WVG-1 & 184 & 23 & 112 & 60.9 & 1 & 0.5 & 48 & 26.1 & 6 & 22 & 20 & 0 & 0 & 2.3 \\
\hline & Mean & & & & 67.9 & & 5.5 & & 19.5 & & & & & & 1.6 \\
\hline CTL-001 & WVG-2 & 220 & 6 & 191 & 86.8 & 7 & 3.2 & 16 & 7.3 & 8 & 4 & 4 & 0 & 0 & 1.8 \\
\hline OAX-123 & WVG-2 & 208 & 2 & 182 & 87.5 & 19 & 9.1 & 5 & 2.4 & 3 & 0 & 1 & 1 & 0 & 2.0 \\
\hline OAX-129 & WVG-2 & 177 & 3 & 148 & 83.6 & 11 & 6.2 & 15 & 8.5 & 9 & 3 & 2 & 1 & 0 & 1.7 \\
\hline OAX-134 & WVG-2 & 228 & 5 & 200 & 87.7 & 12 & 5.3 & 11 & 4.8 & 6 & 5 & 0 & 0 & 0 & 1.5 \\
\hline OAX-135 & WVG-2 & 190 & 6 & 144 & 75.8 & 14 & 7.4 & 26 & 13.7 & 12 & 5 & 8 & 1 & 0 & 1.9 \\
\hline \multirow[t]{2}{*}{ OAX-137 } & WVG-2 & 200 & 9 & 142 & 71.0 & 9 & 4.5 & 40 & 20.0 & 17 & 10 & 10 & 3 & 0 & 2.0 \\
\hline & Mean & & & & 82.1 & & 5.9 & & 9.4 & & & & & & 1.8 \\
\hline CTL-050 & EVG-1 & 174 & 5 & 135 & 77.6 & 8 & 4.6 & 26 & 14.9 & 23 & 2 & 1 & 0 & 0 & 1.2 \\
\hline MA-052 & EVG-1 & 227 & 4 & 168 & 74.0 & 4 & 1.8 & 51 & 22.5 & 28 & 19 & 3 & 1 & 0 & 1.5 \\
\hline MA-058 & EVG-1 & 207 & 7 & 147 & 71.0 & 12 & 5.8 & 41 & 19.8 & 34 & 6 & 0 & 1 & 0 & 1.2 \\
\hline OAX-077 & EVG-1 & 231 & 6 & 192 & 83.1 & 2 & 0.9 & 31 & 13.4 & 20 & 9 & 1 & 1 & 0 & 1.5 \\
\hline OAX-192 & EVG-1 & 131 & 1 & 96 & 73.3 & 1 & 0.8 & 33 & 25.2 & 11 & 21 & 1 & 0 & 0 & 1.7 \\
\hline \multirow[t]{2}{*}{ OAX-216 } & EVG-1 & 200 & 3 & 154 & 77.0 & 6 & 3.0 & 37 & 18.5 & 18 & 18 & 1 & 0 & 0 & 1.5 \\
\hline & Mean & & & & 76.0 & & 2.8 & & 19.1 & & & & & & 1.4 \\
\hline
\end{tabular}


Table 3. Petrography of Formative ceramic composition groups.

\begin{tabular}{|c|c|c|c|c|c|c|c|c|c|c|c|}
\hline \multirow[b]{2}{*}{ Sample } & \multirow{2}{*}{$\begin{array}{l}\text { Comp. } \\
\text { group }\end{array}$} & \multirow{2}{*}{$\begin{array}{l}\text { Inclusions } \\
\text { counted }\end{array}$} & \multicolumn{9}{|c|}{$\%$ of mineral grains counted } \\
\hline & & & Qtz & Plag & Kfs/Mc & Per & IF & TF & $\mathrm{Bt}$ & $\mathrm{Hbl}$ & Op \\
\hline CTL-063 & Atzompa & 56 & 8.9 & 75.0 & 0.0 & 0.0 & 1.8 & 76.8 & 0.0 & 1.8 & 0.0 \\
\hline OAX-010 & Atzompa & 37 & 18.9 & 29.7 & 0.0 & 10.8 & 27.0 & 67.6 & 0.0 & 0.0 & 0.0 \\
\hline \multirow[t]{2}{*}{ OAX-045 } & Atzompa & 87 & 12.6 & 42.5 & 0.0 & 0.0 & 24.1 & 66.7 & 0.0 & 0.0 & 4.6 \\
\hline & Mean & & 13.5 & 49.1 & 0.0 & 3.6 & 17.7 & 70.3 & 0.0 & 0.6 & 1.5 \\
\hline MA-028 & WVG-1 & 21 & 61.9 & 14.3 & 0.0 & 4.8 & 0.0 & 19.0 & 0.0 & 0.0 & 4.8 \\
\hline MA-045 & WVG-1 & 51 & 27.5 & 17.6 & 0.0 & 3.9 & 9.8 & 31.4 & 2.0 & 0.0 & 9.8 \\
\hline OAX-040 & WVG-1 & 46 & 39.1 & 17.4 & 0.0 & 0.0 & 4.3 & 21.7 & 6.5 & 0.0 & 6.5 \\
\hline OAX-147 & WVG-1 & 72 & 29.2 & 22.2 & 2.8 & 1.4 & 11.1 & 37.5 & 8.3 & 0.0 & 6.9 \\
\hline OAX-226 & WVG-1 & 43 & 44.2 & 16.3 & 0.0 & 2.3 & 4.7 & 23.3 & 11.6 & 2.3 & 4.7 \\
\hline \multirow[t]{2}{*}{ OAX-259 } & WVG-1 & 49 & 42.9 & 18.4 & 0.0 & 8.2 & 22.4 & 49.0 & 4.1 & 0.0 & 2.0 \\
\hline & Mean & & 40.8 & 17.7 & 0.5 & 3.4 & 8.7 & 30.3 & 5.4 & 0.4 & 5.8 \\
\hline CTL-001 & WVG-2 & 23 & 39.1 & 0.0 & 0.0 & 17.4 & 4.3 & 21.7 & 0.0 & 4.3 & 4.3 \\
\hline OAX-123 & WVG-2 & 24 & 16.7 & 4.2 & 0.0 & 0.0 & 8.3 & 12.5 & 0.0 & 0.0 & 0.0 \\
\hline OAX-129 & WVG-2 & 27 & 63.0 & 0.0 & 0.0 & 7.4 & 0.0 & 7.4 & 0.0 & 0.0 & 0.0 \\
\hline OAX-134 & WVG-2 & 23 & 39.1 & 4.3 & 0.0 & 4.3 & 0.0 & 8.7 & 0.0 & 0.0 & 8.7 \\
\hline OAX-135 & WVG-2 & 40 & 65.0 & 2.5 & 0.0 & 2.5 & 0.0 & 5.0 & 0.0 & 0.0 & 5.0 \\
\hline \multirow[t]{2}{*}{ OAX-137 } & WVG-2 & 49 & 63.3 & 0.0 & 2.0 & 10.2 & 4.1 & 16.3 & 0.0 & 0.0 & 2.0 \\
\hline & Mean & & 47.7 & 1.8 & 0.3 & 7.0 & 2.8 & 11.9 & 0.0 & 0.7 & 3.3 \\
\hline CTL-050 & EVG-1 & 34 & 29.4 & 23.5 & 0.0 & 0.0 & 11.8 & 35.3 & 5.9 & 0.0 & 0.0 \\
\hline MA-052 & EVG-1 & 55 & 60.0 & 14.5 & 0.0 & 3.6 & 12.7 & 30.9 & 3.6 & 1.8 & 0.0 \\
\hline MA-058 & EVG-1 & 53 & 49.1 & 3.8 & 1.9 & 1.9 & 17.0 & 24.5 & 3.8 & 5.7 & 0.0 \\
\hline OAX-077 & EVG-1 & 33 & 33.3 & 18.2 & 0.0 & 6.1 & 21.2 & 45.5 & 3.0 & 3.0 & 0.0 \\
\hline OAX-192 & EVG-1 & 34 & 35.3 & 29.4 & 2.9 & 2.9 & 14.7 & 50.0 & 0.0 & 0.0 & 5.9 \\
\hline \multirow[t]{2}{*}{ OAX-216 } & EVG-1 & 43 & 48.8 & 18.6 & 2.3 & 2.3 & 7.0 & 30.2 & 0.0 & 0.0 & 4.7 \\
\hline & Mean & & 42.7 & 18.0 & 1.2 & 2.8 & 14.1 & 36.1 & 2.7 & 1.8 & 1.8 \\
\hline
\end{tabular}


Table 4. Chi-square analysis of vessel status by production source through time.

Rosario - MA-I

\begin{tabular}{l|ccc|cc} 
& \multicolumn{3}{c}{ Ceramic Counts } & \multicolumn{2}{c}{ Cell Chi-Sq. } \\
Producer & Costly & Low Cost & Total & Costly & Low Cost \\
\hline Cacaotepec-Atzompa & 0 & 2 & 2 & 1.22 & 1.93 \\
WVG-1 & 0 & 1 & 1 & 0.61 & 0.97 \\
EVG-1 & 18 & 9 & 27 & 0.10 & 0.21 \\
EVG-2 & 3 & 2 & 5 & 0.00 & 0.00 \\
EVG-3 & 2 & 0 & 2 & 0.49 & 0.78 \\
Tilcajete & 3 & 0 & 3 & 0.74 & 1.16 \\
Ocotlán & 1 & 4 & 5 & 1.39 & 2.19 \\
SJM-TL & 3 & 1 & 4 & 0.12 & 0.20 \\
\hline Total & 30 & 19 & 49 & 4.67 & 7.44
\end{tabular}

Late MAI-II

\begin{tabular}{l|ccc|rr} 
& \multicolumn{3}{c}{ Ceramic Counts } & \multicolumn{2}{c}{ Cell Chi-Sq. } \\
Producer & Costly & Low Cost & Total & Costly & Low Cost \\
\hline Atzompa & 37 & 2 & 39 & $\mathbf{4 0 . 4 8}$ & $\mathbf{2 1 . 5 9}$ \\
WVG-1 & 0 & 14 & 14 & 4.87 & 2.60 \\
EVG-1 & 1 & 42 & 43 & $\mathbf{1 3 . 0 2}$ & $\mathbf{6 . 9 5}$ \\
EVG-2 & 9 & 25 & 34 & $\mathbf{0 . 6 8}$ & 0.36 \\
EVG-3 & 1 & 7 & 8 & 1.14 & 0.61 \\
NVG & 1 & 20 & 21 & $\mathbf{5 . 4 4}$ & 2.90 \\
Tilcajete & 20 & 18 & 38 & 3.48 & 1.86 \\
Dainzú & 1 & 4 & 5 & 0.31 & 0.17 \\
Ocotlán & 1 & 2 & 3 & 0.00 & 0.00 \\
SJM-TL & 1 & 1 & 2 & 0.13 & 0.07 \\
\hline Total & 72 & 135 & 207 & 69.55 & 37.11
\end{tabular}

MA II

\begin{tabular}{l|ccc|rr} 
& \multicolumn{3}{c}{ Ceramic Counts } & \multicolumn{2}{c}{ Cell Chi-Sq. } \\
Producer & Costly & Low Cost & Total & Costly & Low Cost \\
\hline Atzompa (MA) & 56 & 0 & 56 & 7.95 & 17.50 \\
WVG-1 & 7 & 3 & 9 & 0.11 & 0.23 \\
WVG-2 & 29 & 2 & 31 & 2.77 & 6.10 \\
EVG-1 & 14 & 22 & 36 & 4.67 & 10.27 \\
EVG-2 & 27 & 3 & 31 & 1.97 & 4.35 \\
EVG-3 & 1 & 22 & 23 & 13.88 & 30.53 \\
Ocotlán & 8 & 12 & 20 & 2.40 & 5.29 \\
SJM-TL & 1 & 1 & 2 & 0.10 & 0.23 \\
\hline Total & 143 & 65 & 208 & 33.85 & 74.50
\end{tabular}

